\title{
Biodiesel Production Processes and Sustainable Raw Materials
}

\author{
Marta Ramos ${ }^{1,2} \mathbb{D}$, Ana Paula Soares Dias ${ }^{2, * \mathbb{D}}$, Jaime Filipe Puna ${ }^{1,2} \mathbb{D}$, João Gomes ${ }^{1,2} \mathbb{D}$ and \\ João Carlos Bordado ${ }^{2}$
}

1 ADEQ, Instituto Superior de Engenharia de Lisboa, Instituto Politécnico de Lisboa, R. Conselheiro Emídio Navarro, 1, 1959-007 Lisboa, Portugal; martasaramos@tecnico.ulisboa.pt (M.R.); jpuna@deq.isel.ipl.pt (J.F.P.); jgomes@deq.isel.ipl.pt (J.G.)

2 LAETA, IDMEC, CERENA, Instituto Superior Técnico, Universidade de Lisboa, Av. Rovisco Pais, 1, 1049-001 Lisboa, Portugal; jcbordado@tecnico.ulisboa.pt

* Correspondence: apsoares@tecnico.ulisboa.pt

Received: 16 October 2019; Accepted: 12 November 2019; Published: 20 November 2019

\begin{abstract}
Energy security and environmental concerns, related to the increasing carbon emissions, have prompted in the last years the search for renewable and sustainable fuels. Biodiesel, a mixture of fatty acids alkyl esters shows properties, which make it a feasible substitute for fossil diesel. Biodiesel can be produced using different processes and different raw materials. The most common, first generation, biodiesel is produced by methanolysis of vegetable oils using basic or acid homogeneous catalysts. The use of vegetable oils for biodiesel production raises serious questions about biodiesel sustainability. Used cooking oils and animal fats can replace the vegetable oils in biodiesel production thus allowing to produce a more sustainable biofuel. Moreover, methanol can be replaced by ethanol being totally renewable since it can be produced by biomass fermentation. The substitution of homogeneous catalyzed processes, nowadays used in the biodiesel industry, by heterogeneous ones can contribute to improve the biodiesel sustainability with simultaneous cost reduction. From the existing literature on biodiesel production, it stands out that several strategies can be adopted to improve the sustainability of biodiesel. A literature review is presented to underline the strategies allowing to improve the biodiesel sustainability.
\end{abstract}

Keywords: biodiesel; sustainability; vegetable oils; animal fats; methanolysis; ethanolysis

\section{World Energy}

Worldwide energy demand has been growing in the last decades (Figure 1a). According to the U.S. Energy Information Administration (EIA) report, this trend will carry on, with an estimated growth in energy consumption of 28\% between 2015 and 2040 [1]. Only in 2018, the world primary energy consumption grew $2.9 \%$ [2].

World use of petroleum and other fuels has been growing as well, being the largest growth in the transport and industrial sector. In the transportation sector, fossil fuels continue to supply most of the energy consumed despite the shortage of their reserves [1].

In Africa, Europe and Americas the oil remains the dominant fuel, while natural gas dominates in the Commonwealth of Independent States (CIS) and the Middle East. In the Asia Pacific region, coal is the dominant fuel (Figure 1b). 


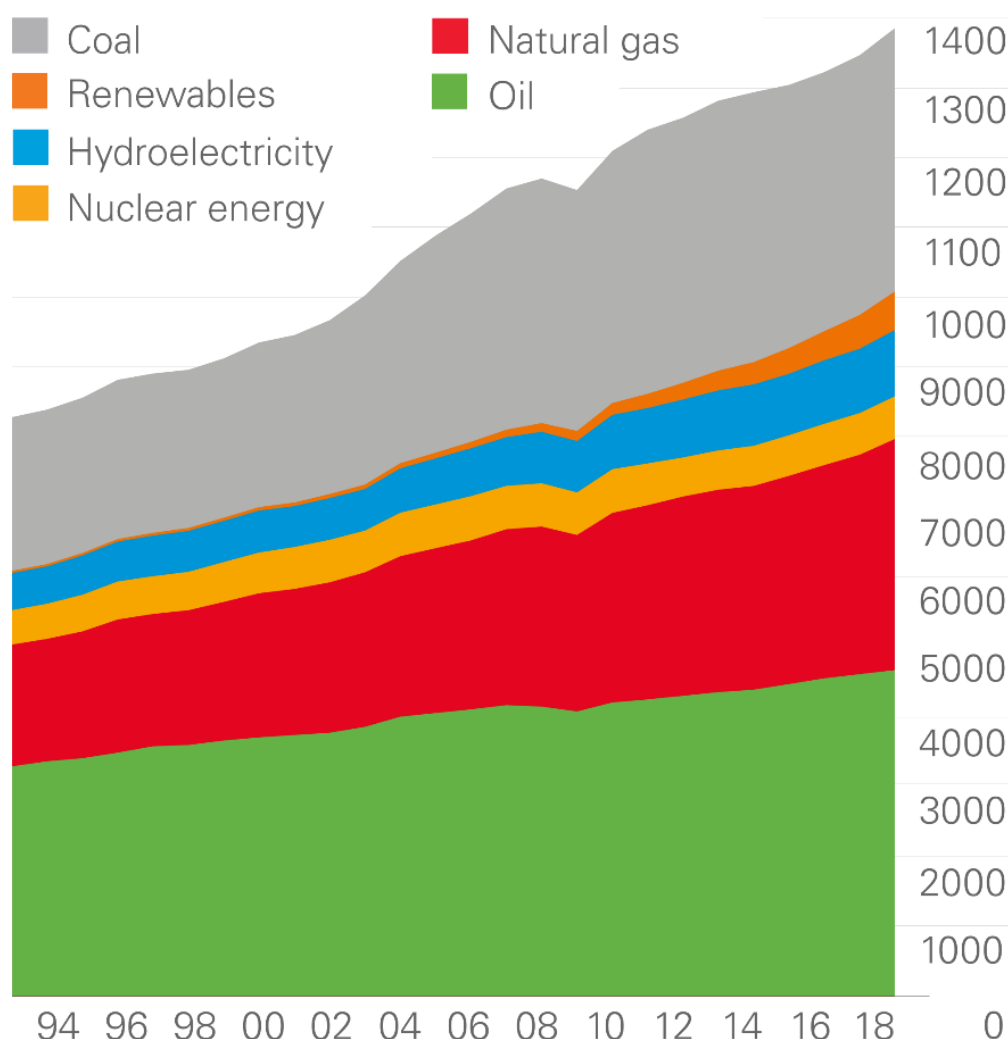

(a)

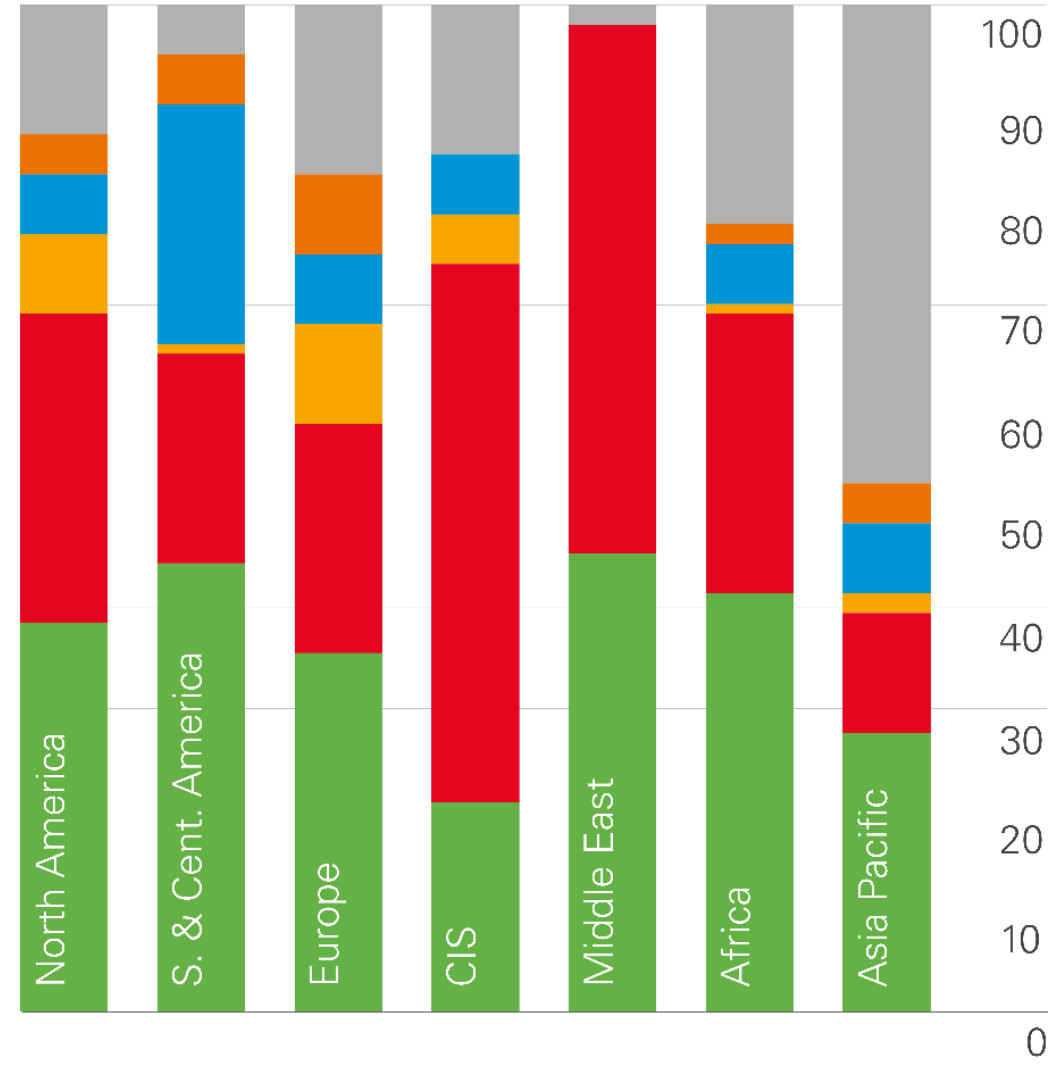

(b)

Figure 1. World Consumption by fuel from 1994 to 2018. (a) (million tones oil equivalent) and Regional Consumption by fuel 2018; (b) (\% of different fuels, color legend in Figure 1a) [2]. 
Replacing fossil fuel with more sustainable energies, maximizing the use of renewable ones, is increasingly important, not only to reduce the emissions of greenhouse gases (GHG) but also to improve energy supply security [3]. These concerns have led to changes in global environmental policy.

In 2007 the European Union launched a climate and energy policy to fight climate change and increase energy security but reinforcing simultaneously its competitiveness. The 2020 package was enacted in legislation in 2009 (Renewable Energy Directive) and sets targets for the year 2020 [4]:

$\checkmark \quad 20 \%$ cut in greenhouse gas emissions (from 1990 levels)

$\checkmark 20 \%$ of EU energy from renewable sources in the energetic mix

$\checkmark \quad 20 \%$ improvement in energy efficiency

The EU also sets binding national targets of minimum energetic incorporation of $10 \%$ for the share of energy from renewable sources consumed by all modes of transport in 2020 [5]. One way to achieve the proposed targets is the increase in the use of biofuels as an alternative energy source. Figure 2 shows the share of renewable energy in transport in 2014, 2015 and 2016 for EU countries.

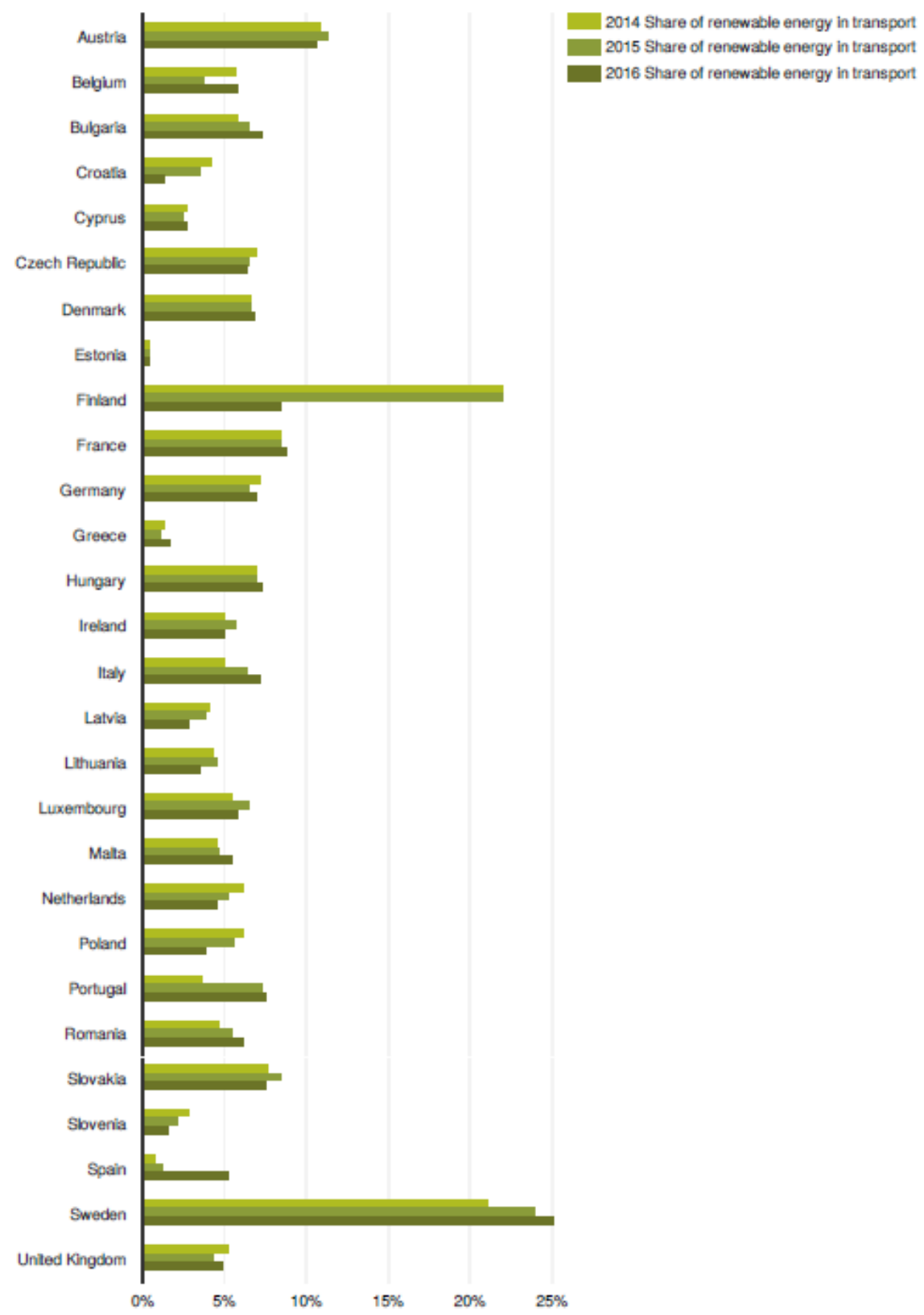

Figure 2. EU share of renewable energy in transport in 2014, 2015 and 2016 [6]. 
The Renewable Energy Directive was reviewed in 2015 (Directive (EU) 2015/1513) limiting to 7\% biofuel production from agri-food-cultures such as cereal and other starch-rich crops, sugars and oil crops used in transport sector [7].

Biofuel production from wastes and residues was also encouraged due to double contribution by double counting for the purpose target. In addition to the current list of raw materials that can be used to produce double counted biofuels (Directive (EU) 2015/1513) it is possible to use raw materials not included in the list but considered as wastes by the national authorities before the adoption of the amendment [7]. Not all countries apply double counting and the definition of waste differs between them.

For example, Portugal is one of the countries that apply double counting, and biofuels produced from animal fats categories I \& II and waste cooking oils, among others, are counted twice. The EU targets for the year 2030 (from 2021 to 2030) had been already established [8]:

$\checkmark \quad$ At least 40\% cuts in greenhouse gas emissions (from 1990 levels)

$\checkmark \quad$ At least 32\% share for renewable energy (upwards revision by 2023)

$\checkmark \quad$ At least $32.5 \%$ improvement in energy efficiency

The EU has also set a new binding national target of minimum energetic incorporation of $14 \%$ for the share of energy from renewable sources consumed in transport until 2030. The 2050 long-term strategy, instead of set targets, creates a vision and defines directions that the EU must take to achieve climate neutrality as well as the Paris Agreement, which established keeping the temperature increase well below $2{ }^{\circ} \mathrm{C}$ compared to pre-industrial levels and the pursuit of efforts to keep it to $1.5^{\circ} \mathrm{C}$, by 2050. Several strategic areas such as energy efficiency; deployment of renewables; clean, safe and connected mobility; competitive industry and circular economy; infrastructure and interconnections; bio-economy and natural carbon sinks; carbon capture and storage to address remaining emissions would have to be worked together to achieve the climate neutrality. In the transport sector an increase in biofuels production due to all alternative fuel options is predicted, which will be required achieving deep emission reductions [9].

\section{Biofuels}

Biofuels are fuels made from biomass, a renewable alternative to fossil fuels. Many of them can be used in the transport sector, like [10]:

- bioethanol: ethanol produced from biomass and/or the biodegradable fraction of waste;

- biodiesel: a methyl-ester produced from vegetable or animal oil, of diesel quality;

- biogas: a fuel gas produced from biomass and/or from the biodegradable fraction of waste, that can be purified to natural gas quality, to be used as biofuel, or wood gas;

- biomethanol: methanol produced from biomass;

- biodimethylether: dimethylether produced from biomass,

- bio-ETBE (ethyl tert-butyl ether): ETBE produced based on bioethanol. The percentage by volume of bio-ETBE that is calculated as a biofuel is $47 \%$;

- bio-MTBE (methyl tert-butyl ether): a fuel produced based on biomethanol. The percentage by volume of bio-MTBE that is calculated as a biofuel is $36 \%$;

- synthetic biofuels: synthetic hydrocarbons or mixtures of synthetic hydrocarbons, which have been produced from biomass;

- biohydrogen: hydrogen produced from biomass, and/or from the biodegradable fraction of waste;

- pure vegetable oil: oil produced from oil plants through pressing, extraction or comparable procedures, crude or refined but chemically unmodified, when compatible with the type of engines involved and the corresponding emission requirements. 
In this sector, the most widely used biofuels around the world are bioethanol, as a substitute for gasoline, and biodiesel, as a substitute for diesel. Other biofuels are also used, although with more limited market access.

\subsection{Biodiesel}

Biodiesel, a mixture of alkyl esters produced of fatty acids is highlighted out as a feasible renewable and low carbon substitute of fossil diesel for the transportation sector [5]. Biodiesel can be used pure or blended with petroleum diesel due to its complete miscibility. Biodiesel blends are referred to as Bxx, where the $\mathrm{xx}$ indicates the amount of blend. Thus, B100 corresponds to pure biodiesel, and a B80 blend is $80 \%$ biodiesel and $20 \%$ petroleum diesel by volume.

Worldwide Europe is the main producer of biodiesel as a result of the environmental policy (Figure 3). Diverse feedstocks can be employed in biodiesel production. Nowadays biodiesel worldwide production is still dominated by vegetable oils: soybean, rapeseed, and palm oil. In the USA the main raw material used is soybean oi, with a $52 \%$ share of total biodiesel feedstocks, followed by canola oil and corn oil with 13\% each [11]. In Europe, rapeseed oil was the major feedstock used, with $45 \%$ of the total production in 2017, followed by used cooking oil (UCO) with $21 \%$ and palm oil with $18 \%$ [12]. For example, in Portugal, rapeseed is the main vegetable oil used, followed by soybean oil. Table 1 presents Portugal's biodiesel production in the last years.

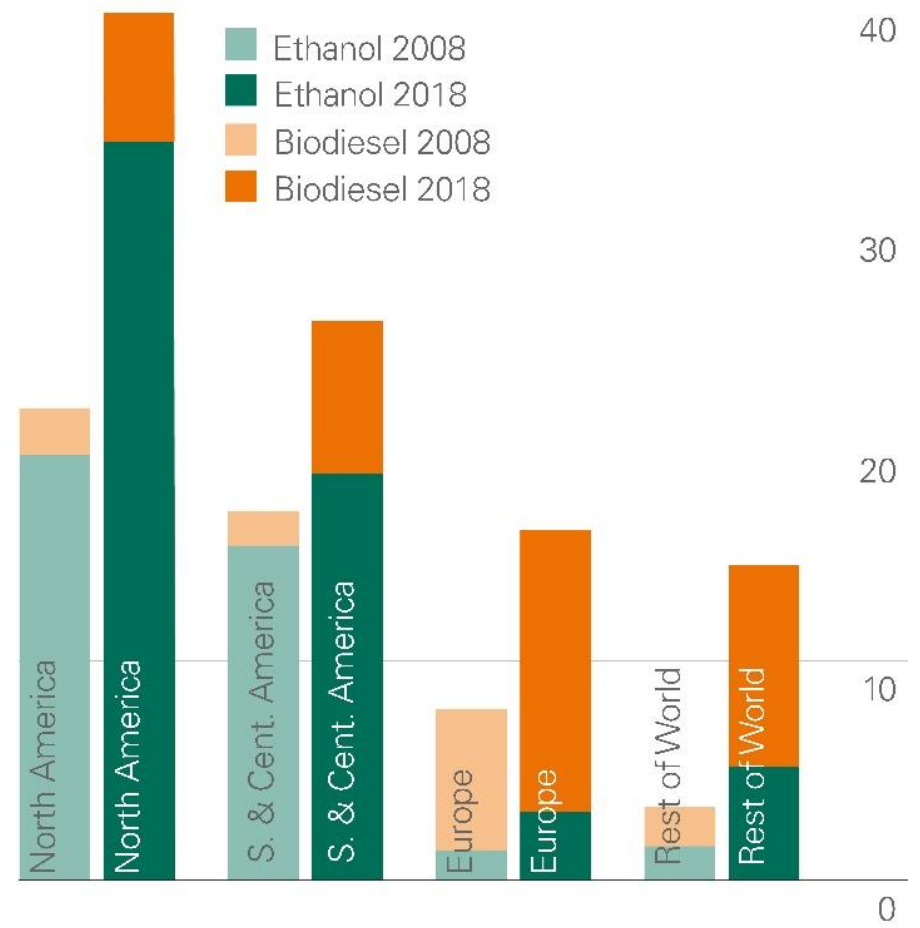

Figure 3. World ethanol and biodiesel production from 2008 to 2018 (vertical axis in million tonnes oil equivalent) [2]. 
Table 1. Biodiesel production from different feedstocks in Portugal (adapted from [13]).

\begin{tabular}{cccccccccc}
\hline \multicolumn{10}{c}{ Biodiesel Production (ton); Year } \\
\hline Feedstock & $\mathbf{2 0 1 0}$ & $\mathbf{2 0 1 1}$ & $\mathbf{2 0 1 2}$ & $\mathbf{2 0 1 3}$ & $\mathbf{2 0 1 4}$ & $\mathbf{2 0 1 5}$ & $\mathbf{2 0 1 6}$ & $\mathbf{2 0 1 7}$ & $\mathbf{2 0 1 8}$ \\
\hline Fresh oils & 316,507 & 365,622 & 304,190 & 299,404 & 324,200 & 287,329 & 205,594 & 175,954 & 151,078 \\
$\quad$ WCO+ & 4810 & 4639 & 4869 & 11,044 & 16,906 & 75,737 & 131,226 & 179,875 & 176,023 \\
animal fat & 21,317 & 370,261 & 309,059 & 310,448 & 341,106 & 363,066 & 336,820 & 355,828 & 327,101 \\
$\quad$ Total & 321,30 \\
\hline
\end{tabular}

\subsection{Advantages and Disadvantages}

The major benefits of using biodiesel as a replacement for diesel fuel are [14-17]:

- Biodegradability;

- Non-flammable and low toxicity;

- Safer to handle;

- Higher combustion efficiency, portability, availability, and renewability;

- Higher cetane number and flash point;

- Lower emissions such as $\mathrm{CO}_{2}, \mathrm{CO}, \mathrm{SO}_{2}$, particulate matter $(\mathrm{PM})$ and hydrocarbons (HC) compared to diesel;

- May be blended with diesel fuel at any proportion;

- No required engine modification up to B20;

- Excellent properties as a lubricant.

There are also some disadvantages of using biodiesel that must be taken into consideration:

- Lower calorific value;

- Higher pour and cloud point fuel;

- Higher nitrous oxide (NOx) emissions (in some cases);

- Higher viscosity and less oxidative stability;

- Biodiesel is corrosive to copper and brass;

- May degrade plastic and natural rubber gaskets and hoses when used in pure form;

- Biodiesel causes excessive engine wear.

The main restriction for biodiesel commercialization is its higher cost in comparison to petroleum fuel. Raw materials price represents $70-95 \%$ of the total production cost [18].

\subsection{Transesterification}

Biodiesel is produced by transesterification of triglycerides with short-chain alcohols in the presence of a catalyst (Scheme 1). Due to the reversibility of the reaction, it is necessary to use an excess of alcohol to drive the reaction equilibrium [19]. However, the transesterification reaction can be done without a catalyst through supercritical process reactions [20]. This process consists of three consecutive reversible reactions where triglycerides are converted into diglycerides, diglycerides are converted into monoglycerides and finally, monoglycerides are converted into glycerol. In addition, for each glyceride that reacts the formation of an ester (biodiesel) molecule occurs [21]. 


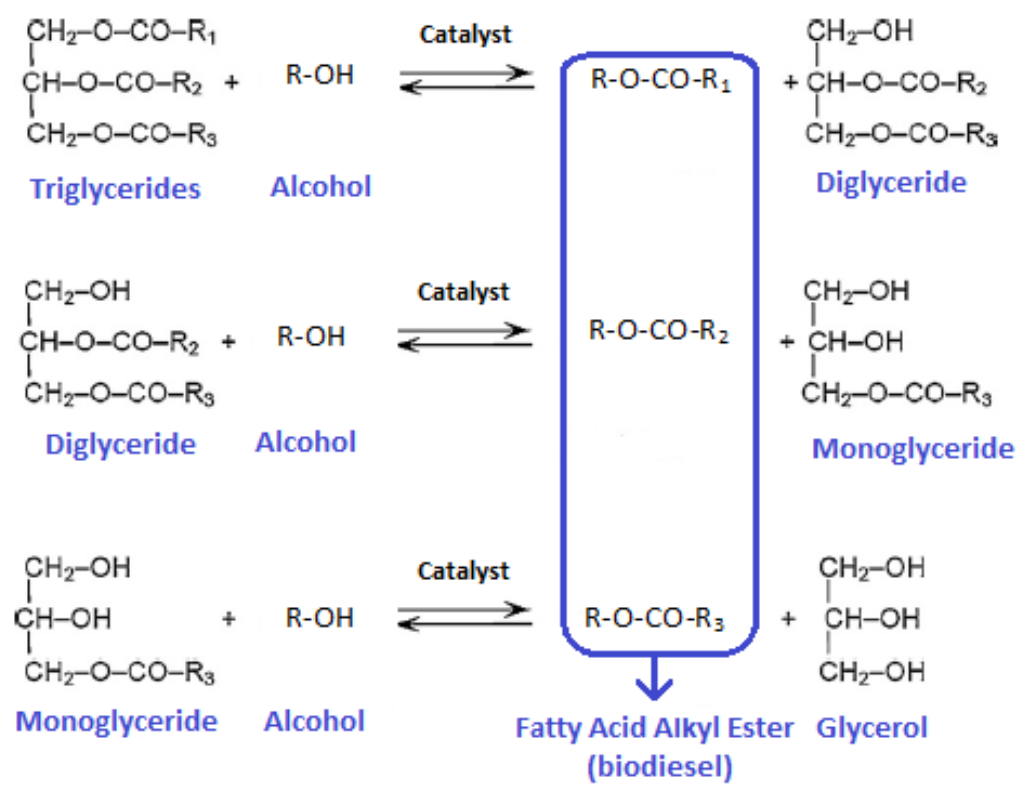

Scheme 1. Transesterification reaction (adapted from [21]).

Various parameters affect the transesterification reaction. In order to produce biodiesel that meets the standard quality parameters, production processes must be optimized [3]. The most relevant, processual and quality, parameters are $[3,22,23]$ :

(1) Free fatty acids, moisture and water content.

(2) Type of alcohol and molar ratio employed.

(3) Type and concentration of catalysts.

(4) Reaction temperature and time.

(5) Rate and mode of stirring.

(6) Purification process of the final product.

(7) Mixing intensity.

(8) Effect of using organic co-solvents.

(9) Specific gravity

Glycerol, also known as glycerin (commercial term, purity $>95 \%$ ), is a by-product of transesterification reactions. About $1 \mathrm{~kg}$ is produced for each $10 \mathrm{~kg}$ of biodiesel [24]. Glycerol is a nontoxic, edible and biodegradable compound used as a raw material in different industries, such as pharmaceuticals, cosmetics, tobacco, textiles or foods [24,25]. Due to its commercial value, in transesterification reaction beyond the biodiesel quality it is also important to obtain glycerol with high purity.

\subsection{Alcohol Used}

In biodiesel production, different alcohols can be used, such as methanol, ethanol, propanol or butanol [26]. The most commonly used are methanol and ethanol, and the reaction product produced when methanol is used is called a fatty acid methyl ester mixture (FAME) whereas if the alcohol is ethanol, the product obtained is a fatty acid ethyl ester mixture (FAEE) [26].

The mild reaction conditions needed, the fast reaction time and the easy phase separation combined with its low-cost and industrial availability make the methanol the most used alcohol in biodiesel production [26,27]. However, the use of this alcohol presents some drawbacks. Methanol is more toxic, volatile and has a lower oil dissolving capacity than ethanol. Although methanol can be obtained from biomass gasification, this alcohol is majorly produced from a fossil sources, about $90 \%$ from natural gas. Thus, the biofuel produced by methanolysis is not considered fully renewable biodiesel [28]. 
Besides, ethanol is made from agricultural products such as potatoes, grain, and corn, allowing this way the production of a renewable fuel [29]. Due to the extra carbon atom, the FAEE produced has a cloud and pour point lower than FAME, which allows the engine to start low temperatures [30]. The combustion heat and the cetane number are higher and the storage properties of FAEE fuel are also improved [27]. The main drawbacks of ethanolysis in biodiesel production are its lower reactivity, compared with methanol, as well as the more difficult separation of FAEE from the coproduced glycerin due to their higher miscibility [31].

Many studies have been carried out to compare the effect of methanol and ethanol on biodiesel production from different feedstocks [32-35]. All achieved results reported that the yield obtained by ethanolysis is lower and more time is needed to complete the reaction than for methanolysis. The separation of FAEE from glycerin is also more difficult. Nevertheless, it allows achieving a completely renewable biodiesel. Although several alcohols can be used to produce biodiesel, so far European Union legislation only covers FAME.

\subsection{Feedstocks}

As mentioned before several feedstocks can be employed in biodiesel production such as vegetable oils (edible and non-edible), waste cooking oils, animal fats and algae oils [36]. The chemical structure is similar in vegetable oils and animal fats, mainly composed by triglycerides with a smaller fraction of diglycerides and monoglycerides [18]. Triglycerides (Figure 4) are formed by one molecule of glycerol combined with three molecules of saturated or unsaturated fatty acid.

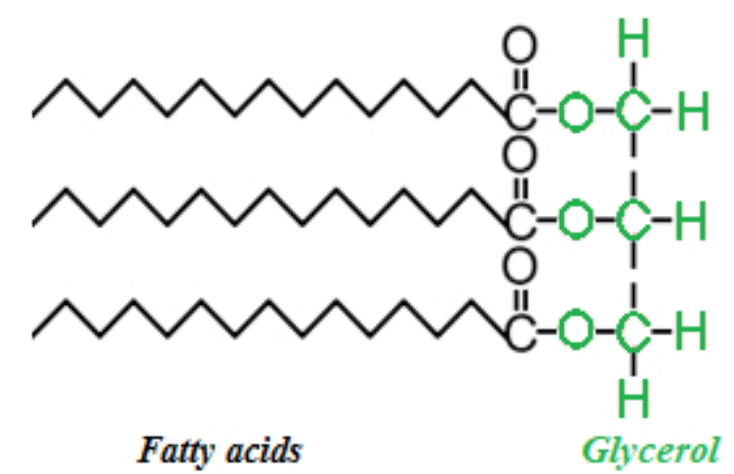

Figure 4. Triglyceride [37].

Both feedstocks are water-insoluble, hydrophobic and soluble in nonpolar organics solvents [18]. The main differences between them are the varied distributions of fatty acids and the high free fatty acids (FFA) content in the fats. The fatty acid profiles of some vegetable oils and animal fats are referenced in Table 2.

Animal fats and greases, at room temperature, tend to be solid due to their high content of saturated fatty acid (carbon-carbon single bond), oils are generally liquids. Refined oils have less FFA, lower acid value, than animal fats, waste grease and waste oils [18]. 
Table 2. Fatty acid profiles of different feedstocks (minima and maxima weight percentages).

\begin{tabular}{|c|c|c|c|c|c|c|c|c|c|c|}
\hline \multirow{2}{*}{ Fatty Acid } & \multirow{2}{*}{$\begin{array}{c}\text { Rapeseed Oil } \\
{[18,38,39]}\end{array}$} & \multirow{2}{*}{$\begin{array}{l}\text { Soybean Oil } \\
{[18,38,40,41]}\end{array}$} & \multirow{2}{*}{$\begin{array}{c}\text { WFO } \\
{[39,41-43]}\end{array}$} & \multirow{2}{*}{$\begin{array}{c}\text { Beef Tallow } \\
{[38,40,44-46]}\end{array}$} & \multirow{2}{*}{$\begin{array}{c}\text { Lard [18,38, } \\
40,44,47]\end{array}$} & \multicolumn{2}{|c|}{ Poultry Fat } & \multicolumn{3}{|c|}{ Fish Oil } \\
\hline & & & & & & $\begin{array}{c}\text { Chicken Fat } \\
{[18,38,40,44,48]}\end{array}$ & $\begin{array}{c}\text { Duck } \\
\text { Tallow [44] }\end{array}$ & $\begin{array}{c}\text { Catfish Fat } \\
\text { [49] }\end{array}$ & $\begin{array}{l}\text { Salmon } \\
\text { Oil [50] }\end{array}$ & $\begin{array}{c}\text { Anchovy } \\
\text { Oil [51] }\end{array}$ \\
\hline Lauric (C12:0) & - & - & $\mathrm{nm}-0.4$ & - & - & $\mathrm{nm}-1.0$ & - & 11.5 & 0.1 & - \\
\hline Myristic (C14:0) & - & $\mathrm{nm}-1.0$ & $\mathrm{~nm}-1.1$ & $2.6-3.5$ & $1.3-1.7$ & $0.5-1.0$ & - & 11.7 & 5.8 & 6.7 \\
\hline Myristoleic (C14:1) & - & - & - & $0.5-1.3$ & - & $0.1-0.2$ & - & 2.0 & - & - \\
\hline Pentadecanoic (C15:0) & - & - & - & $0.5-1.0$ & - & - & - & 1.9 & - & - \\
\hline Palmitic (C16:0) & $3.5-4.5$ & $10.5-11.0$ & $8.4-25.8$ & $23.8-27.0$ & $23.2-25.5$ & $20.9-24.7$ & 17.0 & 28.1 & 16.9 & 20.2 \\
\hline Palmitoleic (C16:1) & $\mathrm{nm}-0.5$ & - & $0.2-4.6$ & $0.5-4.7$ & $2.2-2.7$ & $5.0-7.7$ & - & - & 5.4 & 6.6 \\
\hline Margaric (C17:0) & - & - & - & $1.1-2.5$ & $\mathrm{~nm}-0.4$ & - & - & - & - & 0.2 \\
\hline Heptadecenoic (C17:1) & - & - & - & $0.5-1.7$ & $\mathrm{~nm}-0.4$ & - & - & - & - & - \\
\hline Stearic (C18:0) & $0.9-1.5$ & $3.3-4.8$ & $3.7-4.8$ & $12.7-34.7$ & $10.4-17.0$ & $4.5-5.8$ & 4.0 & - & 4.3 & 4.2 \\
\hline Oleic (C18:1 cis) & - & $22.0-25.4$ & $28.5-52.9$ & $29.9-47.2$ & $40.0-42.8$ & $38.2-48.5$ & 59.4 & 26.8 & 19.2 & 19.7 \\
\hline Linoleic (C18:2) & $18.7-22.3$ & $52.3-54.5$ & $13.5-50.5$ & $0.8-2.7$ & $10.7-21.0$ & $17.3-23.8$ & 19.6 & 6.7 & 16.1 & 2.6 \\
\hline Linolenic (C18:3) & $7.7-9.0$ & $5.3-7.5$ & $0.6-3.5$ & $\mathrm{~nm}-0.8$ & $\mathrm{~nm}-64.7$ & $\mathrm{~nm}-2.5$ & - & - & 2.8 & 1.6 \\
\hline Arachidic (C20:0) & $0.4-0.5$ & $0.4-0.5$ & $0.1-0.4$ & $\mathrm{~nm}-0.3$ & $\mathrm{~nm}-0.2$ & - & - & - & - & - \\
\hline Gadoleic acid (C20:1) & $1.0-2.0$ & $\mathrm{~nm}-0.3$ & $0.1-0.8$ & $\mathrm{~nm}-0.5$ & $0.9-1.0$ & $0.5-1.0$ & - & 2.7 & - & - \\
\hline Eicosadienoic (C20:2) & - & - & - & - & $0.5-0.7$ & - & - & 0.8 & - & 0.2 \\
\hline Eicosatrienoic (C20:3) & - & - & - & - & $\mathrm{nm}-0.2$ & - & - & 0.5 & - & - \\
\hline Eicosapentaenoic (C20:5) & $\mathrm{nm}-0.1$ & - & 0.2 & - & - & - & - & - & 15.6 & 10.4 \\
\hline Behenic (C22:0) & $\mathrm{nm}-0.5$ & $0.4-0.5$ & $\mathrm{~nm}-0.8$ & - & - & - & - & - & - & - \\
\hline Erucic (C22:1) & $\mathrm{nm}-0.1$ & - & - & - & - & - & - & - & - & - \\
\hline Docosapentaenoic (C22:5) & - & - & - & - & - & - & - & - & 2.5 & 0.8 \\
\hline Docosahexanoic (C22:6) & - & - & - & - & - & - & - & - & 11.4 & 21.6 \\
\hline Lignoceric (C24:0) & - & $\mathrm{nm}-0.1$ & $0.04-0.3$ & - & - & - & & - & - & - \\
\hline
\end{tabular}

$\mathrm{nm} —$ not measured. 
Based on their feedstock, biodiesel can be classified into three categories: first, second and third generation (Table 3):

Table 3. Different generations of biodiesel and their feedstocks (adapted from [3]).

\begin{tabular}{|c|c|c|c|}
\hline \multirow{2}{*}{ 1st Generation Edible Oils } & \multicolumn{2}{|c|}{ 2nd Generation } & \multirow{2}{*}{$\begin{array}{l}\text { 3rd Generation } \\
\text { Microalgal Oils }\end{array}$} \\
\hline & Non-Edible Oils & Animal Fats & \\
\hline Soybeans (Glycine max) & Jatropha (Jatropha curcas L.) & Pork lard & Bacteria \\
\hline Rapeseed (Brassica napus L.) & Mahua (Madhuca longifolia) & Beef tallow & $\begin{array}{c}\text { Microalgae } \\
\text { (Chlorella prothecoides) }\end{array}$ \\
\hline $\begin{array}{c}\text { Safflower } \\
\text { (Carthamus tinctorius L.) }\end{array}$ & Coffee grounds & Poultry fat & $\begin{array}{c}\text { Microalgae } \\
\text { (Chlorella vulgaris) }\end{array}$ \\
\hline Rice bran oil (Oryza sativa L.) & Camelina (Camelina sativa) & Fish oil & $\begin{array}{c}\text { Microalgae } \\
\text { (Botryococcus braunii) }\end{array}$ \\
\hline Barley (Hordeum vulgare L.) & $\begin{array}{c}\text { Cottonseed } \\
\text { (Gossypium hirsutum) }\end{array}$ & Chicken fat & $\begin{array}{l}\text { Microalgae } \\
\text { (Chlorella sorokiana) }\end{array}$ \\
\hline Sorghum (Sorghum bicolor) & Tall fescue & & \\
\hline Wheat (Triticum aestivum) & (Festuca arundinacea) & & \\
\hline Corn (Zea mays) & Neem (Azadirachta indica) & & \\
\hline Coconut (Cocos nucifera) & Jojoba (Simmondsia chinensis) & & \\
\hline Canola (Brassica napus) & Passion seed & & \\
\hline Peanut (Arachis hypogaea) & Moringa (Moringa oleifera) & & \\
\hline Palm (Arecaceae) & $\begin{array}{c}\text { Tobacco seed } \\
\text { (Nicotiana tabacum) }\end{array}$ & & \\
\hline $\begin{array}{c}\text { Sunflower } \\
\text { (Helianthus annuus) }\end{array}$ & $\begin{array}{l}\text { Rubber tree seed } \\
\text { (Hevea brasiliensis) }\end{array}$ & & \\
\hline $\begin{array}{c}\text { Palm kernel } \\
\text { (Elaeis guineensis) }\end{array}$ & Nag champa (Plumeria) & & \\
\hline
\end{tabular}

First generation refers to biodiesel derived from edible vegetable oils. The most commonly used are rapeseed, palm, soybean, coconut, peanut, and sunflower [52]. The vegetable oils are widely available and relatively easier to convert into biodiesel. However, the use of edible vegetable oils in the production of biofuel raises several ethical issues. Edible vegetable oils come from food crops. The use of arable land, water, and fertilizer in "growing fuel" instead of food not only affects the food price but also sustainability issues [52].

Furthermore, even if the total amount of edible oils available was used in the production of biodiesel, it was not enough to meet today's diesel requirements. These concerns ally with the double counting of biofuels produced from wastes, which have led to an increasing search for more sustainable feedstocks.

Second generation biofuels are biodiesels derived from non-edible crops or feedstocks that have already fulfilled their food purpose such as waste oily streams from the oil refinery, waste cooking oils (WCOs), greases and waste animal fats (WAFs) [53]. The non-edible crops can be grown on lands that cannot be used for arable crops that have a lower necessity of water or fertilizer to grow, making their plantation more economic [53]. The WCO refers to vegetable oils or animal fats that had been heated and used for cooking different types of food. During this process, various chemical reactions occur such as hydrolysis, polymerization, and oxidation modifying the physical and chemical properties of oil/fat [54]. Recycled fats, based on their FFA level, can be divided as yellow or brown grease. The yellow greases have a FFA level of less than $15 \%$ while, brown has more than $15 \%$ [54]. The second generation also includes WAFs or rendered animal fats, this topic will be explored in the next chapter. The use of these less expensive feedstocks (Table 4) reduces the production costs and reuse wastes, without competing with the food market [47]. The prices of feedstocks are unstable.

Third generation are the biodiesels derived from algal biomass.

Independently of the feedstock category used, the physical and chemical properties of the biodiesel are the same [41]. 
Table 4. The prices of the feedstocks $[55,56]$.

\begin{tabular}{cc}
\hline Type & Price \\
\hline soybean oil & 728 USD per ton ${ }^{1}$ \\
rapeseed oil & 827 USD per ton ${ }^{1}$ \\
palm oil & 535 USD per ton $^{1}$ \\
WCO & 610 USD per ton $^{2}$ \\
tallow (category 1) & 400 per ton $^{2}$ \\
\hline
\end{tabular}

${ }^{1}$ December 2018 price; ${ }^{2}$ October 2018 price.

\section{Animal Fats}

Biodiesel production can be also done with animal fats as raw materials such as tallow, lard, poultry fat and fish oils (Figure 5) [18]. Animal fats are wastes or by-products that came from animal meat processing industry and carcasses of livestock, with relatively low prices.
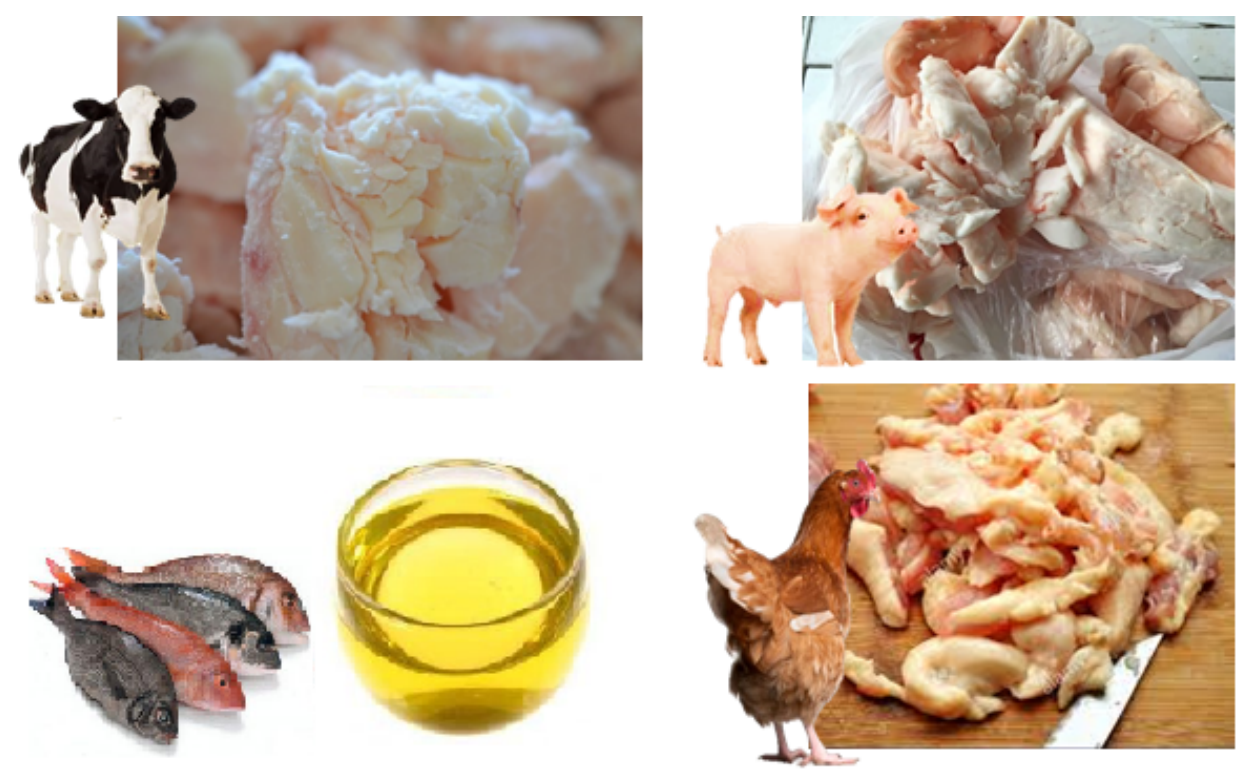

Figure 5. Tallow, lard, fish oil, and poultry fats.

In the European Union the regulation (EC) No 1069/2009 and No 142/2011 lays down health rules as regards animal by-products and derived products not intended for human consumption. These materials can be categorized into three specific categories considering the perceived level of risk to public and animal health [57]:

\section{Category 1 (high risk):}

$\checkmark \quad$ Specified Risk Material (SRM) linked with the transmission of TSEs (Transmissible Spongiform Encephalopathies), this includes the spinal cord and brain.

$\checkmark \quad$ Fallen stock with SRM

$\checkmark$ Catering waste

$\checkmark \quad$ Anything handled with Category 1

Category 2:

$\checkmark \quad$ Material not fit for human consumption and posing a risk to animals and humans

$\checkmark \quad$ Fallen stock without SRM

Category 3 (lowest risk):

$\checkmark \quad$ Fit for human consumption at the point of slaughter 
Fats are recovered from waste fat tissues by the rendering process. This process depends on the risk category and to prevent contamination between different categories of waste and different species, all processing is done on separated lines [57].

Many types of rendering are used in the industry. All of them involve the application of heat, the extraction of moisture, and the separation of fat [58]. The fat can mainly be recovered from wet or dry rendering. In wet rendering (Figure 6), the fat is recovered by heating in the presence of water. Boiling in water and/or steam at a high temperature can be employed [58,59]. The color of the fat produced by this process is clearer. The free fatty acid content increases due to the long contact with water [58].

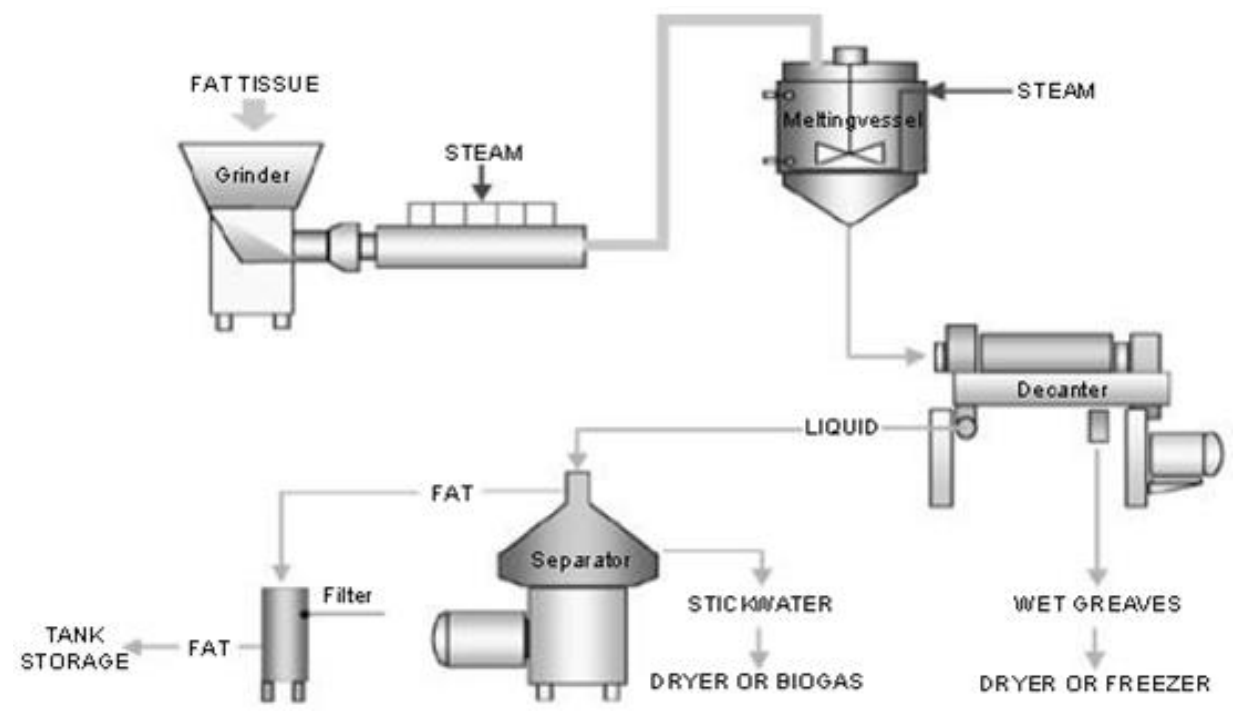

Figure 6. Wet rendering [59].

In dry rendering (Figure 7), in either batch or continuous processes, the fat tissues are cooked in their "own juices" with dry heat [59].

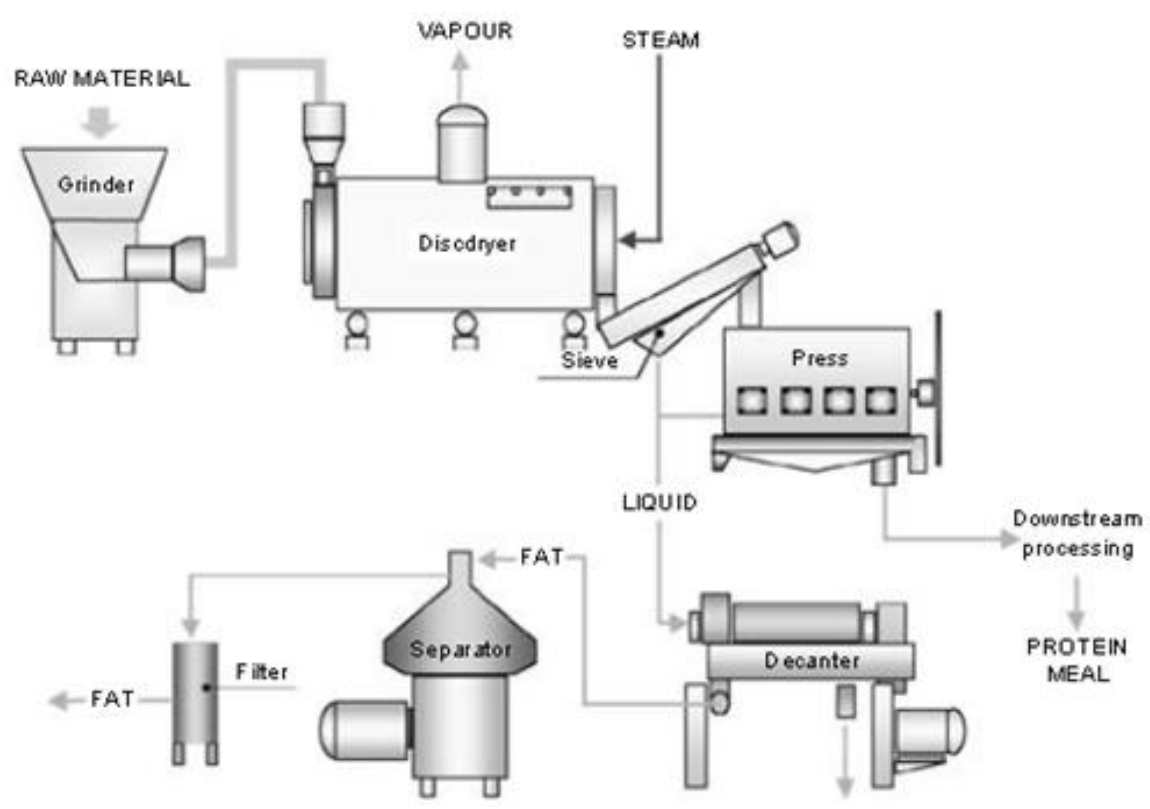

Figure 7. Dry rendering [60].

There is no rule when and where wet or dry rendering is ideal, but it can be observed that the lard and tallow from wet rendering are better than from dry rendering [59]. The rendering process may also be done using an organic solvent. 
Usually, fats are further used in food, pet foods, feed applications but can also be transformed into soaps and oleochemicals (Figure 8), depending on the risk category [61]. All fats can be employed as feedstocks in biodiesel production.

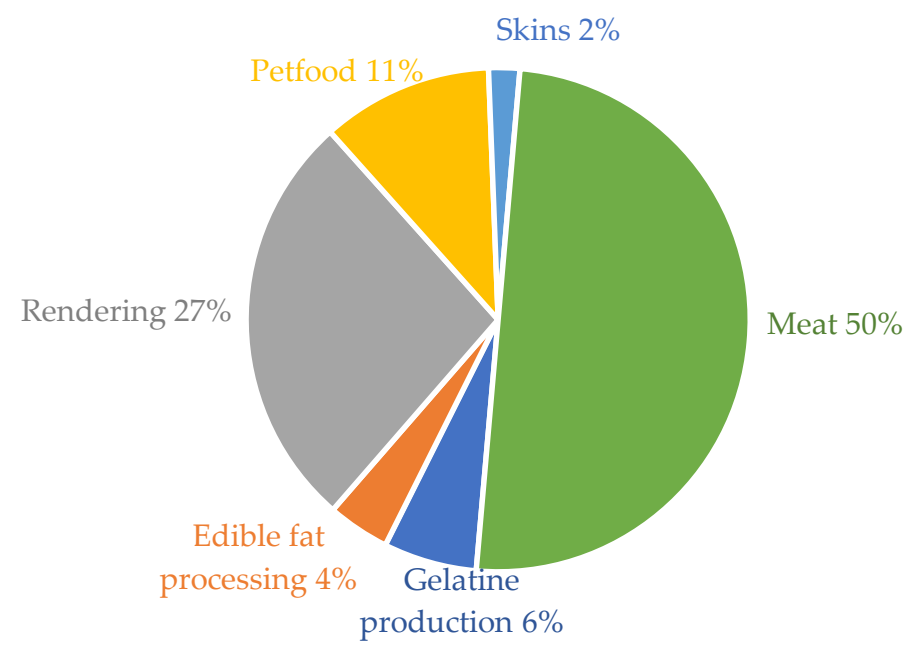

Figure 8. Estimated utilization of slaughtered animal (by \% weight) [60].

\subsection{Biodiesel Production from Animal Fats Versus Vegetable Oils}

In terms of emission of pollutant gases, the advantages of replacing diesel with biodiesel produced from animal fats or obtained from vegetable oils are similar, since the emissions from burning generate similar results. However, Wyatt et al. have reported that three animal fats-based B20 biodiesel blends obtained from lard, beef tallow and chicken fat had lower nitrogen oxide (NOx) emission levels than B20 blend produced from soy oil [40].

In comparison with biodiesel from vegetable origin, biodiesel from animal fats has several advantages. Due to its lower content of unsaturated fatty acids, biodiesel produced from animal fats has a higher cetane number than biodiesel from the most vegetable oils and diesel fuel $[18,36]$. The cetane number increases with the increment of fatty acid carbon chains and the increase in degree of saturation [62]. A higher cetane number is recognized to lower NOx emissions [36]. Biofuel from animal fats has also a higher calorific value [36]. A nonconsensual issue is the oxidative stability of animal-based biodiesel. Some authors claim that animal fat-based biodiesel is less stable for oxidation due to the absence of natural oxidants as compared to biodiesel from vegetable oil [63-65]. On the other hand, others, claim that from the content of saturated fatty acid, the addition of animal fat improves the oxidative stability of biofuel $[36,66,67]$. Feedstocks rich in polyunsaturated fatty acids are more susceptible to oxidation, due to the presence of double bonds in the chains, than feedstocks rich in saturated or monounsaturated fatty acids [68].

Pereira et al. evaluated the effect of blending vegetable with animal-based biodiesel on the oxidative degradation of this biofuel. The authors reported that blends of soybean/beef tallow biodiesel presented a higher oxidative stabilities in comparison with soybean biodiesel [67]. Wyatt et al. also reported that the oxidative stability of biofuel from lard, beef tallow, and chicken fat is equivalent or better than soybean biodiesel [40]. However, Sendzikiene et al. [69] showed that biofuel from animal fats such as lard and tallow is less stable for oxidation than rapeseed and linseed oil. Fuel produced from fats has also some disadvantages, such as the higher cold filter plugging point (CFPP) due to a significant content of saturated fatty acids [63-65]. The CFPP refers to the lowest temperature at which a given volume of liquid fuel will still flow through a specific filter in a specified time when cooled under certain conditions [70]. This is an important property to cold temperature countries. 


\subsection{Catalysts for Biodiesel Production}

In order to increase the reaction rate, the transesterification reaction needs to be catalyzed [20].

The catalyst is a substance that increases the reaction rate without being consumed. If the catalysis acts in the same phase as the reaction mixture is a homogeneous catalyst. However, if the catalysts acts in different phase it is classified as a heterogeneous catalyst [26]. In this case, the chemical reaction occurs at the interface between the two phases [71]. Figure 9 shows the different types of catalysts that can be used in the transesterification process.

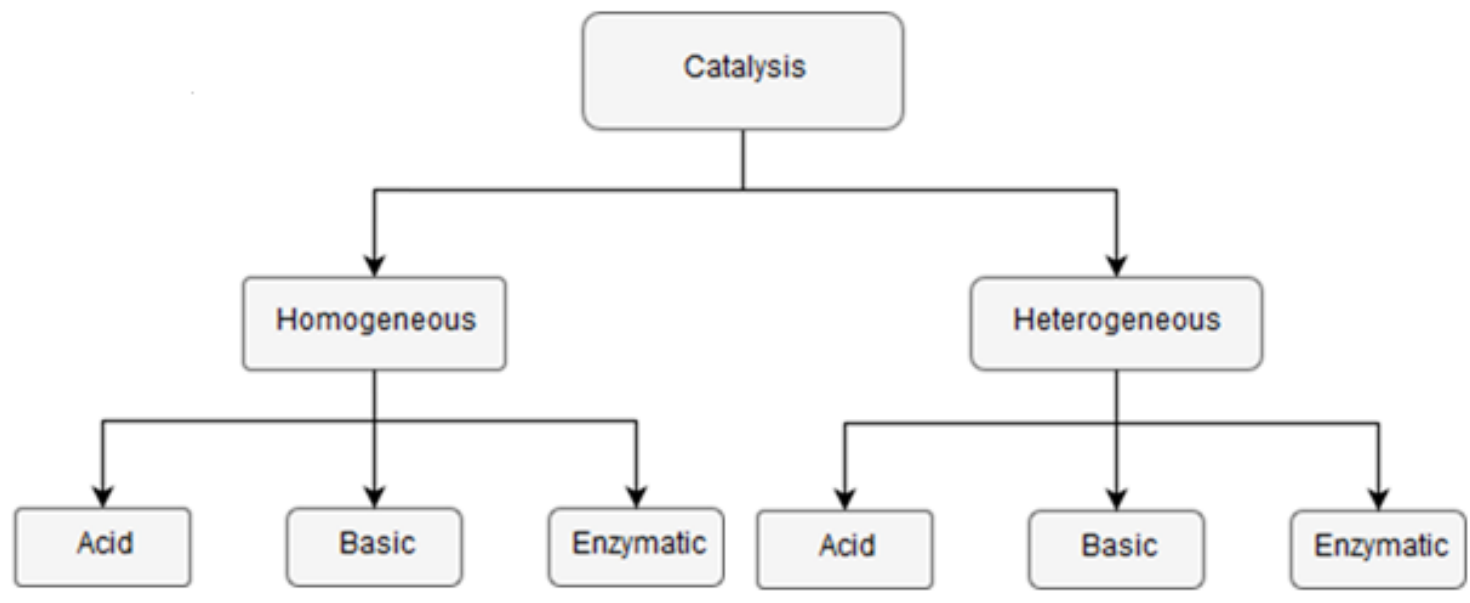

Figure 9. Different types of catalysis employed in the transesterification process.

Homogeneous catalysts have the main advantage of acting in the same phase of the reaction mixture, so the mass transfer resistance is minimized. Depending or their nature they can be basic, acid or enzymatic. These catalysts requires less time for a higher yield and conversion than the heterogeneous one [72].

Currently, the most common catalysts employed in the biodiesel industry are the homogeneous basic ones, such as sodium hydroxide $(\mathrm{NaOH})$ and potassium hydroxide $(\mathrm{KOH})$ that are easily soluble in methanol [22]. Homogeneous basic catalysts, having a higher reaction rate than homogenous acid ones, have the advantage of high biodiesel yield achieved in short reaction time under mild operating conditions. However, high purity feedstocks are essential and such catalytic systems should not be used with low grade fats feedstock which contains a high concentration of FFA and moisture. The FFA reacts with the basic catalyst forming soaps (Scheme 2), which leads to the losses of catalyst and reduced the biodiesel yields.
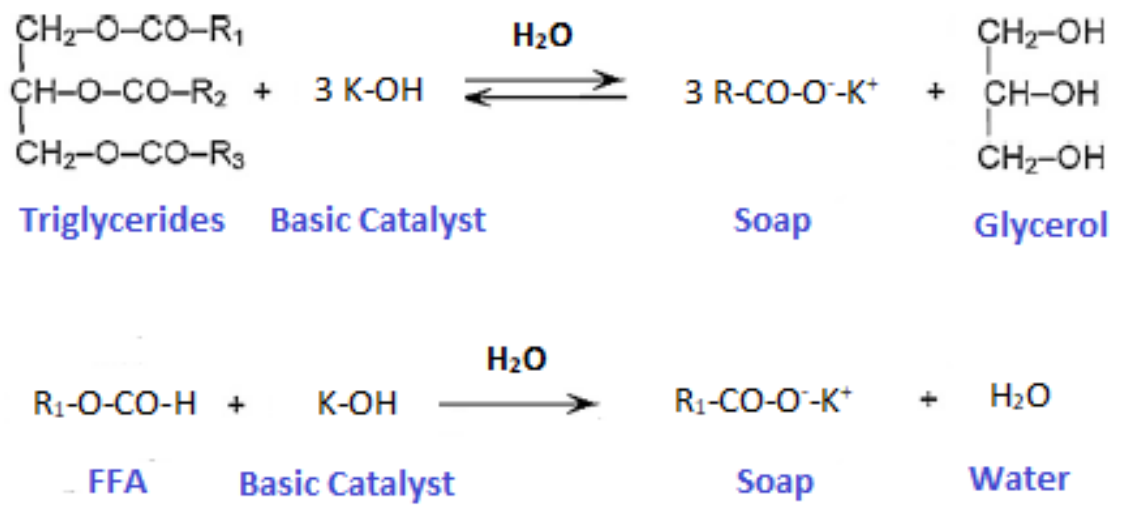

Scheme 2. Saponification reaction of triglycerides and Neutralization reaction of FFA (adapted from [26]). 
The feedstocks moisture, and the water formed in the above reaction (Scheme 2), can also hydrolyze the triglycerides into diglycerides and FFA, increasing the acidity index and decreasing the biodiesel yields, according to the reaction in Scheme 3.

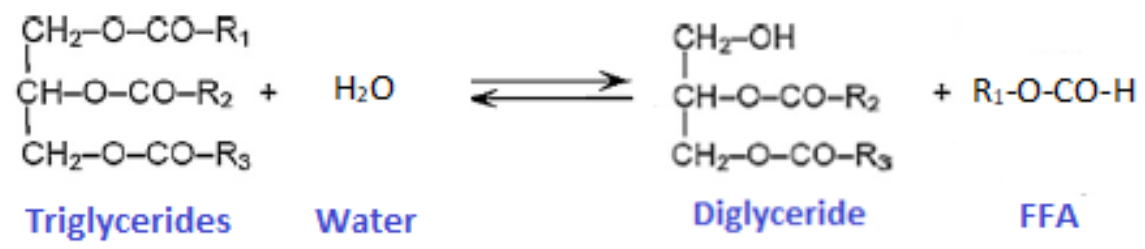

Scheme 3. Hydrolysis of triglycerides in FFA (adapted from [26]).

In order to overcome this issue, the transesterification reaction can be done in two stages. First, FFAs are converted into esters through pretreatment of the feedstock with an acid catalyst, reducing the FFA level (Scheme 4), followed by alkali transesterification. Another possibility is the use of a homogeneous acid catalyst such as sulfuric acid $\left(\mathrm{H}_{2} \mathrm{SO}_{4}\right)$ or hydrochloric acid $(\mathrm{HCl})$. Acid catalysts are not affected by FFA or water content due to their simultaneously capacity to catalyze both transesterification and esterification reactions (Scheme 4). Although, the acid catalyzed reaction is slower and thus, severe reaction conditions are needed, such as high reaction temperature, high acid catalyst concentration, and high alcohol:oil molar ratio in comparison with basic catalysts.

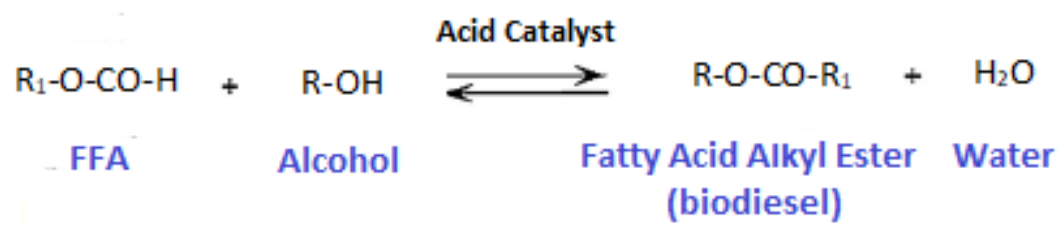

Scheme 4. Esterification reaction of FFA (adapted from [26]).

Homogeneous catalysts cannot be separated from the reaction mixtures so they cannot be reused or regenerated, which is their major drawback. Besides that, these are corrosive to reactors and their separation from the reaction mixture is more difficult, requiring more complex equipment [73,74]. In the homogeneous catalysis purification process, a large amount of water is needed to neutralize and purify the biodiesel, producing a large quantity of wastewater, and increasing the production costs.

In the last decades, there has been a growing interest in the development and employment of new heterogeneous catalysts for biodiesel production. Heterogeneous or solid catalysts can be easily recovered, regenerated and reused. Depending or their nature they can be basic like alkaline earth metal oxides ( $\mathrm{CaO}, \mathrm{MgO})$, hydrotalcite, acids like zirconia and alumina-based catalysts or enzymatic, like immobilized lipase [74,75]. Heterogeneous catalysts facilitate continuous reactor operation as they are easily separated from the reaction medium. They also minimize biodiesel and glycerin purification steps. Water consumption decreases because no catalyst neutralization process, and consequent steps, are required [21,74]. Like the homogeneous basic catalysts, the performance of basic solid catalysts is also affected by high FFA and water content, is also more active than solid acid one with mild operating conditions requirements. Mass transfer resistance is an issue when using heterogeneous catalysts due to the presence of three phases (oil/alcohol/catalyst) in the reaction mixture. In comparison with a homogeneous catalyst, solid catalyst presents lower conversions requiring more severe reaction conditions to achieve the same conversions [21,74]. Another issue to consider is the leaching of the active phase into the reaction mixture. The catalyst leaching leads to a homogeneous contribution. The extent of the catalyst leaching affects not only the life expectancy of catalysts and consequently their reuse but also the biodiesel quality [76]. For these reasons the heterogeneous catalyst should not be leaching and must be reused. 
Lipases are enzymes that can be used in biodiesel production as catalysts, belonging to the homogeneous if used in its free form or heterogeneous group if immobilized [75]. Compared with other catalysts, enzymes have high selectivity, the products achieved (biodiesel and glycerin) are purer and no soaps are formed. Like acid catalysis (homogeneous or heterogeneous), enzymes have the capacity to catalyzed both triglycerides by transesterification and FFA by the esterification reaction. The main disadvantages are its high costs and the risk of enzyme inactivation by the short chain alcohols and products [75,77]. A literature survey on advantages and disadvantages of both homogeneous and heterogeneous catalysis is presented in Table 5.

Table 5. Advantages and disadvantages of homogeneous and heterogeneous catalysts in biodiesel production.

\begin{tabular}{|c|c|c|}
\hline & Advantages & Disadvantages \\
\hline Homogeneous & $\begin{array}{l}\text { Less time required with a higher yield } \\
\text { Mild operation condition } \\
\text { Base catalysts are more active than acid } \\
\text { Acid catalysts are not affected by the content of FFA } \\
\text { or water simultaneously capacity to catalyzed } \\
\text { transesterification and esterification reaction }\end{array}$ & $\begin{array}{l}\text { Not separable from the reaction } \\
\text { mixture, cannot be reuse } \\
\text { A large amount of water is needed to } \\
\text { neutralize and purify the biodiesel } \\
\text { Base catalysts are affected by high } \\
\text { FFA and water content }\end{array}$ \\
\hline Heterogeneous & $\begin{array}{l}\text { Easily recovered, regenerated and reused } \\
\text { Available to batch or continuous fixed bed reactors } \\
\text { Requires fewer process units with a simpler } \\
\text { separation and purification processes } \\
\text { The amount of water is reduced } \\
\text { Base catalysts are more active than acid } \\
\text { Acid catalysts are not affected by the FFA or water } \\
\text { amount, capacity to catalyzed both } \\
\text { transesterification and esterification reaction }\end{array}$ & $\begin{array}{l}\text { Lower conversions requiring more } \\
\text { severe reaction conditions to achieve } \\
\text { the same conversions of } \\
\text { homogeneous ones } \\
\text { Mass transfer resistance due to the } \\
\text { presence of three phases } \\
\text { (oil/alcohol/catalyst) in the } \\
\text { reaction mixture } \\
\text { Base catalysts are affected by high } \\
\text { FFA and water content }\end{array}$ \\
\hline
\end{tabular}

\subsection{Homogeneous and Heterogeneous Catalytic Conversion of Animal Fats}

Animal fats can be used as feedstocks to produces biodiesel through homogenously- (Table 6) and heterogeneously- (Table 7) catalyzed processes. Tables 6 and 7 summarize the main characteristics of both types of catalyzed processes.

\subsection{Biodiesel Purification}

After the transesterification reaction, biodiesel must be purified in order to accomplish the quality specifications (ASTM D6751 or EN 14214) and for further commercialization. In heterogeneous catalysis, in the first step, the solid catalyst can be easily recovered from the reaction mixture by filtration, instead, homogeneous ones will be dispersed and cannot be reused. 
Table 6. Review of homogeneous catalysis to process animal fats.

\begin{tabular}{|c|c|c|c|c|c|c|c|c|c|c|c|c|c|c|}
\hline \multirow[b]{2}{*}{ Feedstock } & \multirow[b]{2}{*}{$\begin{array}{l}\text { Alcohol } \\
\text { Type }\end{array}$} & \multirow[b]{2}{*}{$\begin{array}{l}\text { Catalyst/ } \\
\text { Co-Solvent }\end{array}$} & \multirow[b]{2}{*}{ Reaction } & \multicolumn{4}{|c|}{ Reaction Conditions } & \multicolumn{6}{|c|}{ Optimized Condition } & \multirow[b]{2}{*}{$\operatorname{Re}$} \\
\hline & & & & $\begin{array}{l}\text { Alcohol:Oil } \\
\text { (Molar } \\
\text { Ratio) }\end{array}$ & $\begin{array}{l}\text { Cat. Conc. } \\
\text { (wt \% Oil) }\end{array}$ & $\begin{array}{l}\text { Temp. } \\
\left({ }^{\circ} \mathrm{C}\right) \text { and } \\
\text { Impeller } \\
\text { Speed }\end{array}$ & $\begin{array}{l}\text { Time } \\
\text { (h) }\end{array}$ & Catalyst & $\begin{array}{l}\text { Alcohol:Oil } \\
\text { (Molar } \\
\text { Ratio) }\end{array}$ & $\begin{array}{l}\text { Cat. Conc. } \\
\text { (wt \% Oil) }\end{array}$ & $\begin{array}{l}\text { Temp. } \\
\left({ }^{\circ} \mathrm{C}\right) \text { and } \\
\text { Impeller } \\
\text { Speed }\end{array}$ & $\begin{array}{c}\text { Time } \\
\text { (h) }\end{array}$ & $\begin{array}{c}\mathrm{Y}=\text { Yield } ; \mathrm{C}= \\
\text { Conversion; } \\
\mathrm{P}=\text { Purity }(\%)\end{array}$ & \\
\hline $\begin{array}{l}\text { Mix of WFO } \\
\text { and pork lard } \\
\text { (fat fraction of } \\
\text { mix } 0-1(w / w) \text { ) }\end{array}$ & $\mathrm{MeOH}$ & $\mathrm{NaOH}$ & - & $6: 1$ & 0.8 & 60 & 1 & - & $6: 1$ & 0.8 & 60 & 1 & $\begin{array}{l}\mathrm{Y}=81.7-87.7 \\
\mathrm{P}=93.9-96.3\end{array}$ & [47] \\
\hline beef tallow & \multirow{4}{*}{$\mathrm{MeOH}$} & \multirow{4}{*}{$\mathrm{KOH}$} & \multirow{4}{*}{-} & \multirow{4}{*}{$6: 1$} & \multirow{4}{*}{1} & \multirow{4}{*}{$\begin{array}{l}60 \text { and } \\
60\end{array}$} & \multirow{4}{*}{2} & \multirow{4}{*}{ - } & \multirow{4}{*}{$6: 1$} & \multirow{4}{*}{1} & \multirow{4}{*}{$\begin{array}{c}60 \text { and } \\
60\end{array}$} & \multirow{4}{*}{2} & $\mathrm{Y}=90.6$ & \multirow{4}{*}{78} \\
\hline pork lard & & & & & & & & & & & & & $\mathrm{Y}=91.4$ & \\
\hline chicken fat & & & & & & & & & & & & & $\mathrm{Y}=76.8$ & \\
\hline sardine oil & & & & & & & & & & & & & $\mathrm{Y}=89.5$ & \\
\hline corn oil & \multirow{6}{*}{$\mathrm{MeOH}$} & $\mathrm{KOH}$ & \multirow{6}{*}{-} & \multirow{6}{*}{-} & \multirow{6}{*}{-} & \multirow{6}{*}{$\begin{array}{l}60 \text { and } \\
300 \mathrm{rpm}\end{array}$} & 2 & $\mathrm{KOH}$ & $6: 1$ & 1 & & 2 & $Y=91$ & \multirow{6}{*}[79]{} \\
\hline \multirow{3}{*}{ chicken fat } & & $\begin{array}{l}\text { 1st PT: } \\
\mathrm{H}_{2} \mathrm{SO}_{4}\end{array}$ & & & & & 1 & $\begin{array}{l}\text { 1st PT: } \\
\mathrm{H}_{2} \mathrm{SO}_{4}\end{array}$ & $\begin{array}{c}45 \mathrm{~kg} \\
\text { oil/40.5 kg } \\
\text { alcohol }\end{array}$ & $2.4 \mathrm{~kg}$ & & 1 & Y (experiment & \\
\hline & & $\begin{array}{l}\text { 2nd PT: } \\
\mathrm{H}_{2} \mathrm{SO}_{4}\end{array}$ & & & & & 1 & $\begin{array}{l}\text { 2nd PT: } \\
\mathrm{H}_{2} \mathrm{SO}_{4}\end{array}$ & $\begin{array}{c}40 \mathrm{~kg} \\
\text { fat } / 3.1 \mathrm{~kg} \\
\text { alcohol }\end{array}$ & $0.1 \mathrm{~kg}$ & $\begin{array}{c}60 \text { and } \\
300 \mathrm{rpm}\end{array}$ & 1 & $\begin{array}{c}1)=80.4 ; \mathrm{Y} \\
(\text { experiment } 2) \\
=81.5\end{array}$ & \\
\hline & & $\mathrm{KOH}$ & & & & & 2 & $\mathrm{KOH}$ & $6: 1$ & 1 & & 2 & & \\
\hline \multirow[t]{2}{*}{ fleshing oil } & & $\begin{array}{l}\text { 1st PT: } \\
\mathrm{H}_{2} \mathrm{SO}_{4}\end{array}$ & & & & & 1 & $\begin{array}{l}\text { 1st PT: } \\
\mathrm{H}_{2} \mathrm{SO}_{4}\end{array}$ & $\begin{array}{c}50 \mathrm{~kg} \\
\text { oil/21.1 kg } \\
\text { alcohol } \\
\end{array}$ & $0.62 \mathrm{~kg}$ & & 1 & $\begin{array}{c}\text { Y (experiment } \\
1)=81.6 ; \mathrm{Y} \\
\text { (experiment 2) }\end{array}$ & \\
\hline & & $\mathrm{KOH}$ & & & & & 2 & $\mathrm{KOH}$ & $7.5: 1$ & 1 & & 2 & $=82.3$ & \\
\hline beef tallow & $\mathrm{MeOH}$ & $\begin{array}{c}\text { methanolic } \\
\mathrm{KOH}\end{array}$ & - & - & - & - & - & - & - & - & $70-90$ & $65 \mathrm{~min}$. & $\mathrm{Y}=96.26$ & [80] \\
\hline beef tallow, & $\mathrm{MeOH}$ & $\mathrm{KOH}$ & - & $6: 1$ & 0.8 & $\begin{array}{c}60 \text { and } \\
60\end{array}$ & 2 & - & $6: 1$ & 0.8 & $\begin{array}{c}60 \text { and } \\
60\end{array}$ & 2 & $\mathrm{Y}=90.8$ & \multirow{3}{*}[81]{} \\
\hline pork lard & & & & & & & & & & & & & $Y=91.5$ & \\
\hline chicken fat & & & & & & & & & & & & & $\mathrm{Y}=76.8$ & \\
\hline
\end{tabular}


Table 6. Cont.

\begin{tabular}{|c|c|c|c|c|c|c|c|c|c|c|c|c|c|c|}
\hline & & & & Reaction & Conditions & & & & & Optimize & Condition & & & \\
\hline Feedstock & $\begin{array}{l}\text { Alcohol } \\
\text { Type }\end{array}$ & $\begin{array}{l}\text { Catalyst/ } \\
\text { Co-Solvent }\end{array}$ & Reaction & $\begin{array}{l}\text { Alcohol:Oil } \\
\text { (Molar } \\
\text { Ratio) }\end{array}$ & $\begin{array}{l}\text { Cat. Conc. } \\
\text { (wt \% Oil) }\end{array}$ & $\begin{array}{l}\text { Temp. } \\
\left({ }^{\circ} \mathrm{C}\right) \text { and } \\
\text { Impeller } \\
\text { Speed }\end{array}$ & $\begin{array}{l}\text { Time } \\
\text { (h) }\end{array}$ & Catalyst & $\begin{array}{c}\text { Alcohol:Oil } \\
\text { (Molar } \\
\text { Ratio) }\end{array}$ & $\begin{array}{l}\text { Cat. Conc. } \\
\text { (wt \% Oil) }\end{array}$ & $\begin{array}{l}\text { Temp. } \\
\left({ }^{\circ} \mathrm{C}\right) \text { and } \\
\text { Impeller } \\
\text { Speed }\end{array}$ & $\begin{array}{l}\text { Time } \\
\text { (h) }\end{array}$ & $\begin{array}{c}\mathrm{Y}=\text { Yield } ; \mathrm{C}= \\
\text { Conversion; } \\
\mathrm{P}=\text { Purity }(\%)\end{array}$ & Ref. \\
\hline \multirow{2}{*}{$\begin{array}{l}\text { Mix of waste } \\
\text { fish oil(WFO); } \\
\text { palm oil (PO) } \\
\text { and WFO }\end{array}$} & $\mathrm{MeOH}$ & 1st: $\mathrm{H}_{2} \mathrm{SO}_{4}$ & - & $6: 1$ & 1 & 60 & 1 & - & $6: 1$ & 1 & 60 & 1 & $\begin{array}{c}\text { FAME content } \\
(33.3 \text { wt } \% \text { PO; } \\
66.7 \text { wt } \% \text { WFO) } \\
=80\end{array}$ & [82] \\
\hline & & 2nd: $\mathrm{NaOH}$ & - & 9:1 & 0.5 & 60 & 1 & - & 9:1 & 0.5 & 60 & 1 & $\begin{array}{c}\mathrm{Y}(33.3 \mathrm{wt} \% \\
\mathrm{WFO} ; 66.7 \mathrm{wt} \% \\
\mathrm{PO})=98.5\end{array}$ & \\
\hline $\begin{array}{c}\text { pork lard } \\
\text { blended with } \\
n \text {-hexane } \\
\text { solvent }\end{array}$ & $\mathrm{MeOH}$ & $\mathrm{KOH}$ & - & 6:1-18:1 & $0.48-3.05$ & $50-60$ & 2 & - & $10: 1$ & 2.0 & 60 & 2 & $\begin{array}{c}\mathrm{Y}(65 \mathrm{wt} \% \\
\text { solvent) }=98.2\end{array}$ & [83] \\
\hline $\begin{array}{c}\text { Cyprinus } \\
\text { carpio fish oil }\end{array}$ & $\mathrm{MeOH}$ & $\begin{array}{c}\mathrm{KOH} ; \mathrm{CH}_{3} \mathrm{ONa} ; \\
\mathrm{NaOH} ; \\
\text { EtONa/n-hexane; } \\
\text { pet. ether; } \\
\text { acetone; } \\
\text { cyclohexane; } \\
\text { diethyl ether }\end{array}$ & - & - & - & - & - & $\mathrm{KOH}$ & $5: 1$ & 0.6 & 50 & 0.5 & $\begin{array}{c}\mathrm{Y}(1.5: 1 \text { hexane } \\
\text { to methanol } \\
\text { volume ratio) }= \\
98.55 \pm 1.02\end{array}$ & [84] \\
\hline beef tallow & $\mathrm{MeOH}$ & $\mathrm{KOH}$ & - & $6: 1$ & 1.5 & $\begin{array}{l}65 \text { and } \\
400 \mathrm{rpm}\end{array}$ & $180 \mathrm{~min}$ & - & 6:1 & 1.5 & $\begin{array}{l}65 \text { and } \\
400 \mathrm{rpm}\end{array}$ & $180 \mathrm{~min}$ & $\begin{array}{c}\text { ester content }= \\
95-97\end{array}$ & [45] \\
\hline lard & $\mathrm{MeOH}$ & $\mathrm{NaOH}$ & - & $\begin{array}{c}180 \mathrm{~cm}^{3} \\
\mathrm{fat} / 138 \mathrm{~cm}^{3} \\
\mathrm{MeOH}\end{array}$ & $1.4 \mathrm{~g}$ & $40-70$ & 1.5 & - & $\begin{array}{c}180 \mathrm{~cm}^{3} \\
\mathrm{fat} / 138 \mathrm{~cm}^{3} \\
\mathrm{MeOH}\end{array}$ & $1.4 \mathrm{~g}$ & 70 & 1.5 & $\mathrm{Y}=73$ & [85] \\
\hline lard & $\mathrm{MeOH}$ & $\mathrm{KOH}$ & - & $3.48-8.52$ & $0.16-1.84$ & $24.8-75.2$ & $20 \mathrm{~min}$. & - & $7.5: 1$ & 1.26 & 65 & $20 \mathrm{~min}$. & $Y=97.8 \pm 0.6$ & [86] \\
\hline \multirow{2}{*}{$\begin{array}{c}\text { Silurus } \\
\text { triostegus } \\
\text { heckel fish oil }\end{array}$} & \multirow{2}{*}{$\mathrm{MeOH}$} & $\mathrm{KOH}$ & single and & $3: 1-12: 1$ & $0.25-1.0$ & $32-60$ & $0.5-2$ & - & $6: 1$ & 0.50 & 32 & 0.5 & \multirow{2}{*}{$\mathrm{Y} \mathrm{KOH}=96$} & [87] \\
\hline & & $\mathrm{NaOH}$ & $\begin{array}{l}\text { two-step } \\
\text { transesterification }\end{array}$ & $6: 1$ & 0.5 & $32-60$ & 1 & & & & & & & \\
\hline \multirow{4}{*}{ chicken fat } & \multirow{4}{*}{$\mathrm{MeOH}$} & $\mathrm{KOH}$ & \multirow{4}{*}{$\begin{array}{c}\text { Sulfuric acid, } \\
\text { hydrochloric acid } \\
\text { and sulfamic acid } \\
\text { with methanol }\end{array}$} & \multirow{4}{*}{$6: 1$} & \multirow{4}{*}{ - } & \multirow{4}{*}{$25-60$} & \multirow{4}{*}{$1-4$} & \multirow{4}{*}{$\begin{array}{c}\mathrm{K} \\
\text { methoxide }\end{array}$} & \multirow{4}{*}{$6: 1$} & \multirow{4}{*}{1} & \multirow{4}{*}{60} & \multirow{4}{*}{1} & \multirow{4}{*}{$\mathrm{Y} \mathrm{KOMe}=88.5$} & \multirow{4}{*}{ [88] } \\
\hline & & $\mathrm{NaOH}$ & & & & & & & & & & & & \\
\hline & & $\begin{array}{c}\mathrm{KOMe}(32 \% \text { in } \\
\mathrm{MeOH})\end{array}$ & & & & & & & & & & & & \\
\hline & & $\begin{array}{l}\mathrm{NaOMe}(30 \% \text { in } \\
\mathrm{MeOH})\end{array}$ & & & & & & & & & & & & \\
\hline
\end{tabular}


Table 6. Cont.

\begin{tabular}{|c|c|c|c|c|c|c|c|c|c|c|c|c|c|c|}
\hline & & & \multicolumn{5}{|c|}{ Reaction Conditions } & \multicolumn{6}{|c|}{ Optimized Condition } & \multirow[b]{2}{*}{ Ref } \\
\hline Feedstock & $\begin{array}{l}\text { Alcohol } \\
\text { Type }\end{array}$ & $\begin{array}{l}\text { Catalyst/ } \\
\text { Co-Solvent }\end{array}$ & Reaction & $\begin{array}{l}\text { Alcohol:Oil } \\
\text { (Molar } \\
\text { Ratio) }\end{array}$ & $\begin{array}{l}\text { Cat. Conc. } \\
\text { (wt \% Oil) }\end{array}$ & $\begin{array}{l}\text { Temp. } \\
\left({ }^{\circ} \mathrm{C}\right) \text { and } \\
\text { Impeller } \\
\text { Speed }\end{array}$ & $\begin{array}{l}\text { Time } \\
\text { (h) }\end{array}$ & Catalyst & $\begin{array}{l}\text { Alcohol:Oil } \\
\text { (Molar } \\
\text { Ratio) }\end{array}$ & $\begin{array}{l}\text { Cat. Conc. } \\
\text { (wt \% Oil) }\end{array}$ & $\begin{array}{l}\text { Temp. } \\
\left({ }^{\circ} \mathrm{C}\right) \text { and } \\
\text { Impeller } \\
\text { Speed }\end{array}$ & $\begin{array}{l}\text { Time } \\
\text { (h) }\end{array}$ & $\begin{array}{c}\mathrm{Y}=\text { Yield } ; \mathrm{C}= \\
\text { Conversion; } \\
\mathrm{P}=\text { Purity }(\%)\end{array}$ & \\
\hline chicken fat & $\mathrm{MeOH}$ & $\mathrm{KOH}$ & $\begin{array}{l}\text { pre-treatment } \\
\text { sulfuric acid and } \\
\text { methanol }\end{array}$ & $4: 1-8: 1$ & $0.75-1.25$ & 45 & $3-9 \min$ & - & $7: 1$ & 1 & 45 & $9 \mathrm{~min}$ & $Y=94.8$ & [89] \\
\hline beef tallow & $\mathrm{MeOH}$ & $\mathrm{NaOH}$ & $\begin{array}{l}\text { radio frequency } \\
\text { heating }\end{array}$ & $5: 1-9: 1$ & $0.2-0.6$ & - & $\begin{array}{c}\text { RF } \\
\text { heating } \\
1-5 \text { min }\end{array}$ & - & 9:1 & 0.6 & - & $\begin{array}{c}\text { RF } \\
\text { heating } \\
5 \mathrm{~min} .\end{array}$ & $Y=96.3 \pm 0.5$ & [90] \\
\hline tallow & \multirow{3}{*}{$\mathrm{MeOH}$} & \multirow{3}{*}{$\mathrm{KOH}$} & \multirow{3}{*}{ - } & \multirow{3}{*}{$6: 1$} & \multirow{3}{*}{0.8} & \multirow{3}{*}{60} & \multirow{3}{*}{2} & \multirow{3}{*}{-} & \multirow{3}{*}{ 6:1 } & \multirow{3}{*}{0.8} & \multirow{3}{*}{60} & \multirow{3}{*}{2} & $Y=90.8$ & \multirow{3}{*}[91]{} \\
\hline lard & & & & & & & & & & & & & $Y=91.4$ & \\
\hline poultry & & & & & & & & & & & & & $Y=76.8$ & \\
\hline mutton tallow & $\mathrm{MeOH}$ & $\mathrm{KOH}$ & $\begin{array}{l}\text { pre-treatment } \\
\text { sulfuric acid and } \\
\mathrm{MeOH}\end{array}$ & $6: 1$ & $0.35-0.4 \mathrm{~g}$ & $\begin{array}{l}60 \text { and } \\
900 \mathrm{rpm}\end{array}$ & 1.5 & - & $6: 1$ & $0.39 \mathrm{~g}$ & $\begin{array}{l}60 \text { and } \\
900 \mathrm{rpm}\end{array}$ & 1.5 & $Y=93.2$ & [92] \\
\hline $\begin{array}{l}\text { mix of } \\
\text { chicken and } \\
\text { swine fat } \\
\text { residues }\end{array}$ & EtOH & $\mathrm{KOH}$ & $\begin{array}{l}\text { animal fats } \\
\text { pre-treated }\end{array}$ & $6: 1-8: 1$ & $0.44-1.32$ & $30-70$ & 1 & - & $7: 1$ & 0.96 & 30 & 1 & $C=83.5$ & [93] \\
\hline
\end{tabular}

PT = pretreatment. 
Table 7. Review of heterogeneous catalysis to processes animal fats.

\begin{tabular}{|c|c|c|c|c|c|c|c|c|c|c|c|c|c|c|}
\hline \multirow[b]{2}{*}{ Feedstock } & \multirow[b]{2}{*}{$\begin{array}{l}\text { Alcohol } \\
\text { Type }\end{array}$} & \multirow[b]{2}{*}{$\begin{array}{c}\text { Catalyst/ } \\
\text { Co-Solvent }\end{array}$} & \multicolumn{5}{|c|}{ Reaction Conditions } & \multicolumn{6}{|c|}{ Optimized Condition } & \multirow[b]{2}{*}{$\operatorname{Re}$} \\
\hline & & & $\begin{array}{l}\text { Catalyst } \\
\text { Preparation }\end{array}$ & $\begin{array}{c}\text { Alcohol:Oil } \\
\text { (Molar } \\
\text { Ratio) }\end{array}$ & $\begin{array}{l}\text { Cat. Conc. } \\
\text { (wt \% Oil) }\end{array}$ & $\begin{array}{l}\text { Temp. } \\
\left({ }^{\circ} \mathrm{C}\right) \text { and } \\
\text { Impeller } \\
\text { Speed }\end{array}$ & $\begin{array}{l}\text { Time } \\
\text { (h) }\end{array}$ & $\begin{array}{l}\text { Catalyst } \\
\text { Preparation }\end{array}$ & $\begin{array}{c}\text { Alcohol:Oil } \\
\text { (Molar } \\
\text { Ratio) }\end{array}$ & $\begin{array}{l}\text { Cat. Conc. } \\
\text { (wt \% Oil) }\end{array}$ & $\begin{array}{l}\text { Temp. } \\
\left({ }^{\circ} \mathrm{C}\right) \text { and } \\
\text { Impeller } \\
\text { Speed }\end{array}$ & $\begin{array}{l}\text { Time } \\
\text { (h) }\end{array}$ & $\begin{array}{c}\mathrm{Y}=\text { Yield } ; \mathrm{C}= \\
\text { Conversion; } \\
\mathrm{P}=\text { Purity }(\%)\end{array}$ & \\
\hline \multirow{2}{*}{$\begin{array}{l}\text { catfish fat } \\
\text { (Pangasius) }\end{array}$} & \multirow{2}{*}{$\mathrm{MeOH}$} & barnacle & \multirow{2}{*}{$900^{\circ} \mathrm{C}$} & \multirow{2}{*}{ 6:1-15:1 } & \multirow{2}{*}{$2-7$} & \multirow{2}{*}{65} & \multirow{2}{*}{$2-8$} & \multirow{2}{*}{900} & \multirow{2}{*}{ 12:1 } & \multirow{2}{*}{5} & \multirow{2}{*}{65} & \multirow{2}{*}{4} & $\begin{array}{l}\text { FAME content = } \\
97.2 \pm 0.04 \mathrm{wt} \%\end{array}$ & \multirow{2}{*}{49} \\
\hline & & bivalve clam & & & & & & & & & & & $\begin{array}{l}\text { FAME content }= \\
96.9 \pm 0.03 \mathrm{wt} \%\end{array}$ & \\
\hline $\begin{array}{l}\text { waste lard from } \\
\text { piglet roasting } \\
\text { (compared to } \\
\text { heated and } \\
\text { unheated lard }\end{array}$ & $\mathrm{MeOH}$ & $\begin{array}{l}\text { quicklime } \\
\text { and } \mathrm{CaO}\end{array}$ & $\begin{array}{l}\text { Pure } \mathrm{CaO} \\
550^{\circ} \mathrm{C}, 2 \mathrm{~h} \\
\text { Quicklime } \\
550^{\circ} \mathrm{C}, 4 \mathrm{~h}\end{array}$ & $6: 1$ & 5 & $\begin{array}{c}40 ; 50 \\
60 \text { and } \\
900 \mathrm{rpm}\end{array}$ & up to 3 & $\begin{array}{l}\text { Quicklime } \\
550^{\circ} \mathrm{C} 4 \mathrm{~h}\end{array}$ & 6.1 & 5 & $\begin{array}{l}60 ; 900 \\
\text { rpm }\end{array}$ & 1 & $\begin{array}{c}\text { FAME } \\
\text { concentration } \\
\text { waste lard = } \\
97.5 \%\end{array}$ & [94] \\
\hline chicken fat & $\mathrm{MeOH}$ & $\begin{array}{c}\text { crab, cockle } \\
\text { shells and mix }\end{array}$ & $900{ }^{\circ} \mathrm{C}, 2 \mathrm{~h}$ & - & - & - & - & $900{ }^{\circ} \mathrm{C}, 2 \mathrm{~h}$ & $13.8: 1$ & $\begin{array}{c}4.9 \%(1: 1 \\
\text { crab:cockle) }\end{array}$ & 65 & 3 & $P=98.8$ & [48] \\
\hline $\begin{array}{l}\text { commercial-grade } \\
\text { fat }\end{array}$ & $\mathrm{MeOH}$ & $\begin{array}{l}\text { Amberlyst' } \\
\text { A26 OH }\end{array}$ & - & 6:1 & $\begin{array}{c}1-2.7 \mathrm{~mol} / \mathrm{L} \text { of } \\
\mathrm{fat}\end{array}$ & 65 & $\begin{array}{c}60-500 \\
\min \end{array}$ & - & $6: 1$ & $2.2 \mathrm{~mol} / \mathrm{L}$ & 65 & 6 & $\mathrm{Y}=90-95$ & [95] \\
\hline pork lard & $\mathrm{MeOH}$ & CaMnOx & - & $9: 1-27: 1$ & $1: 5$ & $40-60$ & $4-8$ & - & $21: 1$ & 1 & 60 & 8 & $\mathrm{Y}=99.6$ & [64] \\
\hline \multirow{2}{*}{$\begin{array}{l}\text { soybean oil (SBO) } \\
\text { and beef tallow } \\
\text { (bf) }\end{array}$} & $\mathrm{MeOH}$ & \multirow{2}{*}{$\begin{array}{l}\text { Sulfonated } \\
\text { polystyrene } \\
\text { compounds }\end{array}$} & - & $\begin{array}{l}\text { 3:1-9:1; } \\
\text { 100:1 }\end{array}$ & \multirow{2}{*}{$\begin{array}{c}20 \mathrm{~mol} \% \text { of } \\
-\mathrm{SO}_{3} \mathrm{H} \text { groups } \\
\text { in relation to } \\
\text { the oil mass }\end{array}$} & $28-64$ & $3-18$ & - & 100:1 & \multirow{2}{*}{$\begin{array}{c}20 \mathrm{~mol} \% \text { of } \\
-\mathrm{SO}_{3} \mathrm{H} \text { groups } \\
\text { in relation to } \\
\text { the oil mass }\end{array}$} & 64 & 18 & $\mathrm{C}_{\mathrm{SBO}}=85$ & \multirow{2}{*}{96} \\
\hline & EtOH & & - & 100:1 & & 64 & 18 & - & - & & - & - & $\begin{array}{c}C_{\text {Beef tallow }}=85 \\
\text { and 75 }\end{array}$ & \\
\hline beef tallow & $\mathrm{MeOH}$ & $\mathrm{KF} / \mathrm{CaO}-\mathrm{Fe}_{3} \mathrm{O}_{4}$ & - & 3:1-12:1 & $1-6 \mathrm{~g}$ & $40-65$ & $\begin{array}{l}20-70 \\
\text { min. }\end{array}$ & - & 10:1 & $5 \mathrm{~g}$ & 55 & 1 & $\mathrm{Y}=94$ & [97] \\
\hline beef tallow & $\mathrm{MeOH}$ & $\mathrm{Cs}_{2} \mathrm{O} / \gamma-\mathrm{Al}_{2} \mathrm{O}_{3}$ & $\begin{array}{c}\text { wet } \\
\text { impregnation } \\
\text { with aqueous } \\
\text { solution of } \\
\mathrm{Cs}_{2} \mathrm{CO}_{3} \text {. }\end{array}$ & $8: 1-12: 1$ & $4-6 \mathrm{~g}$ & $55-75$ & $\begin{array}{l}80-160 \\
\text { min. }\end{array}$ & - & 10.5:1 & $5.3 \%$ & 66 & 2 & $Y=95.5$ & [98] \\
\hline
\end{tabular}


Biodiesel phase can be separated from the glycerin phase in a decanter by sedimentation or centrifugation due to their density difference $[99,100]$. The excess alcohol used in the reaction can be separated from both phases by evaporation or distillation. The obtained biodiesel still contains free glycerol, soap, residual alcohol, catalyst and mono, di, and triglycerides unreacted, which must be removed. Table 8 summarizes the main consequences of biodiesel contamination on internal combustion engines.

Table 8. Biodiesel impurities and properties effects on internal combustion engines [101,102].

\begin{tabular}{|c|c|c|}
\hline \multirow{2}{*}{ Impurities } & \multicolumn{2}{|c|}{ Effects } \\
\hline & Biodiesel & Engines \\
\hline FFA & Low oxidation stability & Corrosion \\
\hline water & $\begin{array}{l}\text { Reduces the heat of combustion } \\
\text { Hydrolysis (FFA production) }\end{array}$ & $\begin{array}{l}\text { Corrosion } \\
\text { Bacteriological growth (filter blockage) }\end{array}$ \\
\hline methanol & $\begin{array}{l}\text { Low values of density and viscosity } \\
\text { Low flash point (transport, storage, } \\
\text { and use problems) }\end{array}$ & Corrosion of $\mathrm{Al}$ and $\mathrm{Zn}$ pieces \\
\hline glycerides & High viscosity & $\begin{array}{c}\text { Deposits in the injectors (carbon residue) } \\
\text { Crystallization }\end{array}$ \\
\hline $\begin{array}{c}\text { metals } \\
\text { (soap, catalyst) }\end{array}$ & - & $\begin{array}{c}\text { Deposits in the injectors (carbon residue) } \\
\text { Filter blockage (sulfated ashes) } \\
\text { Engine weakening }\end{array}$ \\
\hline glycerin & $\begin{array}{c}\text { Decantation } \\
\text { storage problem }\end{array}$ & Increase aldehydes and acrolein emissions \\
\hline
\end{tabular}

Biodiesel can be purified by several processes. The most used industrial biodiesel purification process is water washing. This method is simple, efficient and allows one to obtain biodiesel with high purity. Distilled water, deionized water, acidulated water, acid and water or water, and an organic solvent can be added to biodiesel $[99,102,103]$. Due to their water solubility, residual glycerol, methanol, catalyst, and any soap formed during the reaction can be eliminated. Lastly, washed biodiesel need to be dehydrated $[99,103]$. Biodiesel purification with water is time-consuming and produces large volumes of wastewater which cannot be discharged in watercourses. Wastewater effluent has to be treated, increasing the biodiesel production costs. To overcome this issue, a dry washing purification process, using solid sorbents such as ion exchange resin, silica, activated carbon among other adsorbents, can be adopted. This purification process is fast, easy to integrate in an industrial plant and being water-free, no wastewater is produced lowering the production cost [102]. The main drawback is the purified biodiesel may not meet methanol and glycerin EN 14214 specifications. Therefore, methanol and glycerin should be removed as much as possible before the purification process [101,104]. Also, the adsorbent cost, its recycling, and elimination can be a disadvantage [105].

Inorganic and polymeric membranes can also be employed for biodiesel purification [104]. Membrane works as a selective barrier retaining the biodiesel contaminants [105]. No water is consumed within this process, consequently, no wastewater is produced although the addition of a small amount of water improves glycerin retention. High-quality biodiesel meeting the required specifications can be achieved. This process presents some issues too such as, membrane cleaning, membrane costs and the increase of biodiesel production cost [103].

\subsection{Quality Specifications}

The quality of biodiesel can be influenced by several factors that may be reflected in its chemical and physical properties. To be commercialized, biodiesel has to accomplish the quality specifications established by institutions like the European Committee of Standardization (ISO) and the American 
Society for Testing and Materials (ASTM) (Table 9). These regulations, which are dynamic and must be periodically reviewed, describe not only the quality requirements but also the test methods employed.

Table 9. ASTM D6751 and EN 14214 specifications of biodiesel fuels (B 100) [106,107].

\begin{tabular}{|c|c|c|c|c|}
\hline Property Specification & $\begin{array}{l}\text { ASTM D6751 } \\
\text { Limit }\end{array}$ & $\begin{array}{c}\text { Test } \\
\text { Methods }\end{array}$ & $\begin{array}{l}\text { EN } 14214 \\
\text { Limit }\end{array}$ & Test Methods \\
\hline Ester content $(\%(\mathrm{~m} / \mathrm{m}))$ & - & - & 96.5 & EN 14103 \\
\hline Density at $15^{\circ} \mathrm{C}\left(\mathrm{kg} / \mathrm{m}^{3}\right)$ & 880 & D1298 & $860-900$ & EN ISO $3675 / 12185$ \\
\hline Viscosity at $40{ }^{\circ} \mathrm{C}\left(\mathrm{mm}^{2} / \mathrm{s}\right)$ & $1.9-6.0$ & D445 & $3.5-5.0$ & EN ISO 3104 \\
\hline Cetane number & Min. 47 & D613 & Min. 51.0 & EN ISO 5165 \\
\hline Iodine number ( $\left.\mathrm{g} \mathrm{I}_{2} / 100 \mathrm{~g}\right)$ & - & - & Max. 120 & EN 14111/16300 \\
\hline Acid value (mg KOH/g) & Max. 0.50 & D664 & Max. 0.50 & EN 14104 \\
\hline Pour point $\left({ }^{\circ} \mathrm{C}\right)$ & -15 to -16 & D97 & - & - \\
\hline Flash point $\left({ }^{\circ} \mathrm{C}\right)$ & Min. 130 & D93 & Min. 101 & EN ISO 2719/3679 \\
\hline Cloud point $\left({ }^{\circ} \mathrm{C}\right)$ & -3 to -12 & D2500 & - & - \\
\hline Cold filter plugging point $\left({ }^{\circ} \mathrm{C}\right)$ & Max. +5 & D6371 & - & EN 116/16329 \\
\hline Copper strip corrosion $\left(3 \mathrm{~h}\right.$ at $\left.50^{\circ} \mathrm{C}\right)$ & No 3 & D130 & class 1 & EN ISO 2160 \\
\hline Carbon residue $(\%(\mathrm{~m} / \mathrm{m}))$ & Max. 0.05 & D4530 & - & - \\
\hline Methanol content $(\%(\mathrm{~m} / \mathrm{m}))$ & Max. 0.20 & EN 14110 & Max. 0.20 & EN 14110 \\
\hline Water content $(\mathrm{mg} / \mathrm{kg})$ & Max. 500 & D2709 & Max. 500 & EN ISO 12937 \\
\hline Sulfur $(\mathrm{mg} / \mathrm{kg}))$ & $\begin{array}{l}\text { S15 Max. } 15 \\
\text { S500 Max. } 500\end{array}$ & D5453 & Max. 10.0 & $\begin{array}{c}\text { EN ISO } \\
20846 / 20884\end{array}$ \\
\hline Sulfated ash $(\%(\mathrm{~m} / \mathrm{m}))$ & Max. 0.02 & D874 & Max. 0.02 & EN ISO 3987 \\
\hline Phosphorus content (mg/kg) & Max. 10 & D4951 & Max. 4.0 & EN 14107/16294 \\
\hline Free glycerol $(\%(\mathrm{~m} / \mathrm{m}))$ & Max. 0.02 & D6584 & Max. 0.02 & EN 14105/EN 14106 \\
\hline Total glycerol (\% (m/m)) & Max. 0.24 & D6548 & Max. 0.25 & EN 14105 \\
\hline Monoglyceride $(\%(\mathrm{~m} / \mathrm{m}))$ & Max. 0.40 & D6584 & Max. 0.70 & EN 14105 \\
\hline Diglyceride $(\%(\mathrm{~m} / \mathrm{m}))$ & - & - & Max. 0.20 & EN 14105 \\
\hline Triglyceride $(\%(\mathrm{~m} / \mathrm{m}))$ & - & - & Max. 0.20 & EN 14105 \\
\hline $\begin{array}{l}\text { Distillation temperature, } 90 \% \\
\text { recovered }\left({ }^{\circ} \mathrm{C}\right)\end{array}$ & Max. 360 & D1160 & - & - \\
\hline Oxidation stability $\mathrm{h}\left(\right.$ at $\left.110^{\circ} \mathrm{C}\right)$ & Min. 3 & EN 15751 & Min. 8 & EN 14112/15751 \\
\hline Linolenic acid methyl ester $(\%(\mathrm{~m} / \mathrm{m}))$ & - & - & Max. 12.0 & EN 14103 \\
\hline $\begin{array}{c}\text { Polyunsaturated }(\geq 4 \text { double bonds) } \\
\text { Methyl esters }(\%(\mathrm{~m} / \mathrm{m}))\end{array}$ & - & - & Max. 1.00 & EN 15779 \\
\hline Alkaline metals $\left(\mathrm{Na}^{+} \mathrm{K}\right)(\mathrm{mg} / \mathrm{kg})$ & Max. 5.0 & EN 14538 & Max. 5.0 & $\begin{array}{c}\text { EN } \\
14108 / 14109 / 14538\end{array}$ \\
\hline $\begin{array}{l}\text { Alkaline earth metals }(\mathrm{Ca}+\mathrm{Mg}) \\
\qquad(\mathrm{mg} / \mathrm{kg})\end{array}$ & Max. 5.0 & EN 14538 & Max. 5.0 & EN 14538 \\
\hline Total contamination (mg/kg) & - & - & Max. 24 & EN 12662 \\
\hline
\end{tabular}

\subsection{Properties of Biodiesel from Different Feedstocks}

Biodiesel properties are influenced not only by raw materials but also by transesterification and purity process. Table 10 shows a literature review of biodiesel properties from different feedstocks. 
Table 10. Biodiesel properties from different feedstocks.

\begin{tabular}{|c|c|c|c|c|c|c|c|c|c|c|c|c|}
\hline Property Specification & $\begin{array}{l}\text { ASTM D6751 } \\
\text { Limit }\end{array}$ & $\begin{array}{c}\text { EN } 14214 \\
\text { Limit }\end{array}$ & $\begin{array}{l}\text { Rapeseed } \\
\text { Oil [3] }\end{array}$ & $\begin{array}{l}\text { Soybean } \\
\text { Oil [3] }\end{array}$ & $\begin{array}{c}\text { Palm Oil } \\
{[3]}\end{array}$ & $\begin{array}{c}\text { Chicken } \\
\text { Fat [79] }\end{array}$ & $\begin{array}{c}\text { Fleshing } \\
\text { Oil [79] }\end{array}$ & $\begin{array}{c}\text { Beef Tallow } \\
{[3,18]}\end{array}$ & $\begin{array}{c}\text { Mutton } \\
\text { Tallow [18] }\end{array}$ & Lard [18] & $\begin{array}{c}\text { Fish Oil } \\
\text { [108] }\end{array}$ & WCO [108] \\
\hline $\begin{array}{c}\text { Density at } 15^{\circ} \mathrm{C} \\
\left(\mathrm{kg} / \mathrm{m}^{3}\right)\end{array}$ & 880 & 860-900 & 882 & 914 & 864 & $867-889.7$ & $875.5-876.7$ & $832-872$ & $856-882$ & $873-877.4$ & $881-890$ & $875-888$ \\
\hline $\begin{array}{l}\text { Viscosity at } 40^{\circ} \mathrm{C} \\
\left(\mathrm{mm}^{2} / \mathrm{s}\right)\end{array}$ & $1.9-6.0$ & $3.5-5.0$ & 4.44 & 4.04 & 4.5 & $4.94-6.25$ & $4.7-4.77$ & $4.89-5.35$ & $4.75-5.98$ & $4.59-5.08$ & $3.82-7.2$ & $3.66-6.8$ \\
\hline Cetane number & Min. 47 & Min. 51.0 & 54.4 & 37.9 & 54.6 & 52.3 & 58.8 & 60.36 & $59-59$ & - & $50.9-52.6$ & $41-66$ \\
\hline $\begin{array}{l}\text { Iodine number ( } \mathrm{g} \\
\mathrm{I}_{2} / 100 \mathrm{~g} \text { ) }\end{array}$ & - & Max. 120 & - & $128-143$ & 54 & 95.5-130 & $53.6-61$ & $\mathrm{~nm}-44.4$ & $40-126$ & $67-77$ & nm-185 & $60-125.21$ \\
\hline $\begin{array}{l}\text { Acid value (mg } \\
\mathrm{KOH} / \mathrm{g})\end{array}$ & Max. 0.50 & Max. 0.50 & - & 0.266 & 0.24 & $0.22-0.8$ & $0.28-0.32$ & $0.147-0.2$ & $0.3-0.65$ & $0.04-1.13$ & $0.35-1.32$ & $0.27-1.31$ \\
\hline Pour point $\left({ }^{\circ} \mathrm{C}\right)$ & -15 to -16 & - & -12 & & 15 & $-6-12.3$ & & $10-15$ & -5 & $5-7$ & $-14-4$ & $-2.5-9$ \\
\hline Flash point $\left({ }^{\circ} \mathrm{C}\right)$ & Min. 130 & Min. 101 & 170 & 254 & 135 & $169-174$ & $168-175$ & $152-171$ & - & $143.5-147$ & $114-176$ & 70.6-190 \\
\hline Cloud point $\left({ }^{\circ} \mathrm{C}\right)$ & -3 to -12 & - & -3.3 & 0.9 & 16 & $-5-14$ & & $\mathrm{~nm}-16$ & -4 & - & -5 & $-12-13$ \\
\hline $\begin{array}{l}\text { Cold filter plugging } \\
\text { point }\left({ }^{\circ} \mathrm{C}\right)\end{array}$ & Max. +5 & - & -13 & -4 & 12 & $2-3$ & $10-11$ & $\mathrm{~nm}-14$ & - & - & - & $-5-12$ \\
\hline $\begin{array}{l}\text { Copper strip corrosion } \\
\left(3 \mathrm{~h} \text { at } 50^{\circ} \mathrm{C}\right)\end{array}$ & No 3 & class 1 & & 1 & 1 & No 1 & No 1 & No 1 & - & No 1 & - & - \\
\hline $\begin{array}{l}\text { Carbon residue }(\% \\
(\mathrm{m} / \mathrm{m}))\end{array}$ & Max. 0.05 & - & 81 & - & - & $\mathrm{nm}-0.024$ & - & - & - & $\mathrm{nm}-0.21$ & $76.53-80.01$ & $0.0004-77.38$ \\
\hline $\begin{array}{l}\text { Methanol content }(\% \\
(\mathrm{m} / \mathrm{m}))\end{array}$ & Max. 0.20 & Max. 0.20 & - & - & - & $0.01-0.06$ & $0.01-0.01$ & $\mathrm{~nm}-0.1$ & - & - & - & - \\
\hline Water content (mg/kg) & Max. 500 & Max. 500 & - & $\begin{array}{l}<0.005 \\
\% \text { vol }\end{array}$ & & $200-440$ & $326-410$ & $\mathrm{~nm}-374.2$ & - & $184-1100$ & - & \\
\hline Sulfur (mg/kg)) & $\begin{array}{l}\text { S15 Max. } 15 \\
\text { S500 Max. } 500\end{array}$ & Max. 10.0 & - & 0.8 & 0.003 & nm-81.5 & 138.1-141 & $\mathrm{nm}-7.0$ & - & - & - & $0-12.5$ \\
\hline Sulfated ash $(\%(\mathrm{~m} / \mathrm{m}))$ & Max. 0.02 & Max. 0.02 & - & $<0.005$ & 0.002 & - & 0.03 & $\mathrm{~nm}-<0.005$ & $\mathrm{~nm}-0.025$ & $\mathrm{~nm}-0.002$ & - & - \\
\hline $\begin{array}{l}\text { Phosphorus content } \\
(\mathrm{mg} / \mathrm{kg})\end{array}$ & Max. 10 & Max. 4.0 & - & 0.1 & $<0.001$ & - & 100 & $\mathrm{~nm}-<0.1$ & $\mathrm{~nm}-16$ & - & - & - \\
\hline Free glycerol (\% (m/m)) & Max. 0.02 & Max. 0.02 & - & 0.012 & 0.01 & $0.008-0.02$ & $0.01-0.01$ & $0.008-0.01$ & - & - & - & - \\
\hline
\end{tabular}


Table 10. Cont.

\begin{tabular}{|c|c|c|c|c|c|c|c|c|c|c|c|c|}
\hline Property Specification & $\begin{array}{c}\text { ASTM D6751 } \\
\text { Limit }\end{array}$ & $\begin{array}{c}\text { EN } 14214 \\
\text { Limit }\end{array}$ & $\begin{array}{l}\text { Rapeseed } \\
\text { Oil [3] }\end{array}$ & $\begin{array}{l}\text { Soybean } \\
\text { Oil [3] }\end{array}$ & $\underset{[3]}{\text { Palm Oil }}$ & $\begin{array}{c}\text { Chicken } \\
\text { Fat [79] }\end{array}$ & $\begin{array}{c}\text { Fleshing } \\
\text { Oil [79] }\end{array}$ & $\begin{array}{c}\text { Beef Tallow } \\
{[3,18]}\end{array}$ & $\begin{array}{c}\text { Mutton } \\
\text { Tallow [18] }\end{array}$ & Lard [18] & $\begin{array}{c}\text { Fish Oil } \\
\text { [108] }\end{array}$ & WCO [108] \\
\hline $\begin{array}{l}\text { Total glycerol (\% } \\
(\mathrm{m} / \mathrm{m}))\end{array}$ & Max. 0.24 & Max. 0.25 & - & 0.149 & 0.01 & $0.03-0.19$ & $0.10-0.05$ & $0.076-0.33$ & - & - & - & - \\
\hline $\begin{array}{l}\text { Monoglyceride (\% } \\
(\mathrm{m} / \mathrm{m}))\end{array}$ & Max. 0.40 & Max. 0.70 & 0.473 & - & & $0.02-0.56$ & $0.06-0.27$ & $0.13-0.223$ & - & - & - & - \\
\hline Diglyceride $(\%(\mathrm{~m} / \mathrm{m}))$ & - & Max. 0.20 & 0.088 & - & & $0.05-0.09$ & $0.02-0.09$ & $0.63-0.12$ & - & - & - & - \\
\hline Triglyceride $(\%(\mathrm{~m} / \mathrm{m}))$ & - & Max. 0.20 & 0.019 & - & & $0.06-0.12$ & $0.04-0.20$ & $0-0.07$ & - & - & - & - \\
\hline $\begin{array}{c}\text { Distillation } \\
\text { temperature, } 90 \% \\
\text { recovered }\left({ }^{\circ} \mathrm{C}\right) \\
\end{array}$ & Max. 360 & - & - & - & - & - & - & $307-344$ & - & $\mathrm{nm}-352.5$ & - & - \\
\hline $\begin{array}{c}\text { Oxidation stability h } \\
\quad\left(\text { at } 110^{\circ} \mathrm{C}\right)\end{array}$ & Min. 3 & Min. 8 & 7.6 & 2.1 & 10.3 & $\mathrm{~nm}-6$ & - & $\mathrm{nm}-1.6$ & - & - & - & $0.43-15.9$ \\
\hline $\begin{array}{l}\text { Linolenic acid methyl } \\
\text { ester }(\%(\mathrm{~m} / \mathrm{m}))\end{array}$ & - & Max. 12.0 & - & - & - & - & - & - & - & $0.9-1.4$ & - & - \\
\hline $\begin{array}{c}\text { Polyunsaturated ( } \geq 4 \\
\text { double bonds) } \\
\text { Methyl esters (\% } \\
(\mathrm{m} / \mathrm{m}))\end{array}$ & - & Max. 1.00 & - & - & - & - & - & - & - & - & - & - \\
\hline $\begin{array}{l}\text { Alkaline metals }\left(\mathrm{Na}^{+}\right. \\
\mathrm{K})(\mathrm{mg} / \mathrm{kg})\end{array}$ & Max. 5.0 & Max. 5.0 & - & - & - & - & 5 & $2-2.63$ & - & $\mathrm{nm}-17.2$ & - & - \\
\hline $\begin{array}{l}\text { Alkaline metals }(\mathrm{Ca}+ \\
\mathrm{Mg})(\mathrm{mg} / \mathrm{kg})\end{array}$ & Max. 5.0 & Max. 5.0 & - & - & - & - & - & - & - & - & - & - \\
\hline $\begin{array}{c}\text { Total contamination } \\
(\mathrm{mg} / \mathrm{kg})\end{array}$ & - & Max. 24 & - & - & - & - & - & - & - & - & - & - \\
\hline $\begin{array}{l}\text { Heat of combustion } \\
(\mathrm{MJ} / \mathrm{kg})\end{array}$ & - & - & 37 & 39.76 & - & $39.34-40.17$ & 39.89-39.95 & 40.23 & - & $36.5-40.10$ & $37.79-42.24$ & $35.40-43.21$ \\
\hline
\end{tabular}




\section{Conclusions}

Biodiesel obtained by alcoholysis of fats is a feasible low carbon fuel to replace the conventional fossil diesel thus helping to mitigate the anthropogenic carbon emissions. First generation biodiesel, obtained by methanolysis of vegetable oils, presents severe sustainability issues related to the use of arable lands to produce energy-dedicated crops (oleaginous crops). Biodiesel sustainability issues can be minimized by using non-edible fats such as animal fats and waste cooking oils. Replacing methanol by ethanol could also contribute to reducing carbon emissions from biodiesel because ethanol can be obtained by biomass fermentation, thus being a renewable alcohol.

Biodiesel production processes can be improved by replacing conventional homogeneous (basic) catalysts with heterogeneous catalysts. Among the huge number of scientific papers on heterogeneous catalysts for biodiesel production, the excellent performances (catalytic activity) of calcium-based catalysts stands out but they have never been tested industrially. The lack of data on the stability of calcium catalysts appears to be a limitation to their industrial testing. Dry-washing purification of biodiesel, instead of the wet process nowadays in use, can also contribute to biodiesel sustainability. Biodiesel dry-washing decreases the large volumes of wastewater generated in the traditional purification method and cuts down the energy required in the biodiesel drying process.

Author Contributions: All authors participated equally in the conception of the presented review and the manuscript was prepared by M.R. and A.P.S.D. and revised by J.G., J.F.P. and J.C.B. contributed to the funding obtaining (PTDC/EMS-ENE/4865/2014).

Funding: The authors acknowledge FCT (Fundação para a Ciência e Tecnologia, Portugal) for funding project PTDC/EMS-ENE/4865/2014. This work was also supported through IDMEC, under LAETA, project FCT UID/EMS/50022/2019.

Conflicts of Interest: The authors declare no conflict of interest.

\section{Abbreviations}

$\begin{array}{ll}\text { ASTM } & \text { American Society for Testing and Materials } \\ \text { CFPP } & \text { Cold Filter Plugging Point } \\ \text { CIS } & \text { Commonwealth of Independent States } \\ \text { EIA } & \text { U.S. Energy Information Administration } \\ \text { ETBE } & \text { Ethyl tert-butyl ether } \\ \text { FAEE } & \text { Fatty acid ethyl ester } \\ \text { FAME } & \text { Fatty acid methyl ester } \\ \text { FFA } & \text { Free fatty acid } \\ \text { GHG } & \text { Greenhouse gas } \\ \text { HC } & \text { Hydrocarbons } \\ \text { ISO } & \text { European Committee of Standardization } \\ \text { MTBE } & \text { Methyl tert-butyl ether } \\ \text { NOx } & \text { Nitrous oxide } \\ \text { PM } & \text { Particulate matter } \\ \text { SRM } & \text { Specified Risk Material } \\ \text { TSE } & \text { Transmissible Spongiform Encephalopathies } \\ \text { UCO } & \text { Used cooking oil } \\ \text { WAF } & \text { Waste animal fats } \\ \text { WCO } & \text { Waste cooking oil }\end{array}$

\section{References}

1. U.S. Energy Information Administration. International Energy Outlook 2017; U.S. Energy Information Administration: Washington, DC, USA, 2017.

2. BP Statistical Review of World Energy 2019, 68th ed.; BP: London, UK, 2019. 
3. Atabani, A.E.; Silitonga, A.S.; Badruddin, I.A.; Mahlia, T.M.I.; Masjuki, H.H.; Mekhilef, S. A comprehensive review on biodiesel as an alternative energy resource and its characteristics. Renew. Sustain. Energy Rev. 2012, 16, 2070-2093. [CrossRef]

4. European Commission 2020 Climate \& Energy Package. Available online: https://ec.europa.eu/clima/ policies/strategies/2020_en?fbclid=IwAR3DhvhN__IcDcqtIu0_sgWiB7cctQrqR90JKNs5dMRxOCxtGV_ FQQVw4QM (accessed on 5 February 2019).

5. European Union Directive (EU) 2009/28. Available online: https://eur-lex.europa.eu/LexUriServ/LexUriServ. do?uri=OJ:L:2009:140:0016:0062:EN:PDF (accessed on 12 February 2019).

6. European Environment Agency (EEA). Use of Renewable Fuels in Transport. Available online: https://www.eea.europa.eu/data-and-maps/indicators/use-of-cleaner-and-alternative-fuels/use-ofcleaner-and-alternative-4 (accessed on 12 February 2019).

7. European Commission Directive (EU) 2015/1513. Available online: https://eur-lex.europa.eu/legal-content/ EN/TXT/?uri=celex\%3A32015L1513 (accessed on 13 February 2019).

8. European Commission 2030 Climate \& Energy Framework. Available online: https:/ec.europa.eu/clima/ policies/strategies/2030_en (accessed on 11 March 2019).

9. European Commission. The Commission Presents Strategy for a Climate Neutral Europe by 2050-Questions and Answers. Available online: https://ec.europa.eu/clima/policies/strategies/2050_en (accessed on 13 March 2019).

10. European Commission Directive (EU) 2003/30. Available online: https://eur-lex.europa.eu/legal-content/EN/ ALL/?uri=celex\%3A32009L0028 (accessed on 13 March 2019).

11. Biodiesel Explained-U.S. Energy Information Administration (EIA). Available online: https://www.eia.gov/ energyexplained/biofuels/biodiesel.php (accessed on 14 April 2019).

12. Phillips, S.; Flach, B.; Lieberz, S.; Lappin, J.; Bolla, S. EU Biofuels Annual $2018 . \quad$ Available online: https://apps.fas.usda.gov/newgainapi/api/report/downloadreportbyfilename?filename=Biofuels $\%$ 20Annual_The\%20Hague_EU-28_7-3-2018.pdf (accessed on 14 April 2019).

13. Direcção Geral de Energía e Geología. Renováveis-Estatísticas Rápidas-No 169; Direcção Geral de Energía e Geología: Lisbon, Portugal, 2018.

14. Mahmudul, H.M.; Hagos, F.Y.; Mamat, R.; Adam, A.A.; Ishak, W.F.W.; Alenezi, R. Production, characterization and performance of biodiesel as an alternative fuel in diesel engines-A review. Renew. Sustain. Energy Rev. 2017, 72, 497-509. [CrossRef]

15. Romano, S.D.; Sorichetti, P.A. Dielectric Spectroscopy in Biodiesel Production and Characterization; Springer: London, UK, 2011.

16. Islam, A.; Ravindra, P. Biodiesel Production with Green Technologies; Springer: Basel, Switzerland, 2016; ISBN 9783319452722.

17. Moser, B.R. Biodiesel production, properties, and feedstocks. Vitr. Cell. Dev. Biol. Plant 2009, 45, $229-266$. [CrossRef]

18. Banković-Ilić, I.B.; Stojković, I.J.; Stamenković, O.S.; Veljkovic, V.B.; Hung, Y.T. Waste animal fats as feedstocks for biodiesel production. Renew. Sustain. Energy Rev. 2014, 32, 238-254. [CrossRef]

19. Banerjee, A.; Chakraborty, R. Parametric sensitivity in transesterification of waste cooking oil for biodiesel production-A review. Resour. Conserv. Recycl. 2009, 53, 490-497. [CrossRef]

20. Shahid, E.M.; Jamal, Y. Production of biodiesel: A technical review. Renew. Sustain. Energy Rev. 2011, 15, 4732-4745. [CrossRef]

21. Avhad, M.R.; Marchetti, J.M. Innovation in solid heterogeneous catalysis for the generation of economically viable and ecofriendly biodiesel: A review. Catal. Rev. 2016, 58, 157-208. [CrossRef]

22. Ajala, O.E.; Aberuagba, F.; Odetoye, T.E.; Ajala, A.M. Biodiesel: Sustainable energy replacement to petroleum-based diesel fuel-A review. Chembioeng Rev. 2015, 2, 145-156. [CrossRef]

23. Mathiyazhagan, M.; Ganapathi, A. Factors affecting biodiesel production. Res. Plant Biol. 2011, 1, 1-5.

24. Tan, H.W.; Abdul Aziz, A.R.; Aroua, M.K. Glycerol production and its applications as a raw material: A review. Renew. Sustain. Energy Rev. 2013, 27, 118-127. [CrossRef]

25. Luo, X.; Ge, X.; Cui, S.; Li, Y. Value-added processing of crude glycerol into chemicals and polymers. Bioresour. Technol. 2016, 215, 144-154. [CrossRef] [PubMed] 
26. Borges, M.E.; Díaz, L. Recent developments on heterogeneous catalysts for biodiesel production by oil esterification and transesterification reactions: A review. Renew. Sustain. Energy Rev. 2012, 16, 2839-2849. [CrossRef]

27. Avramović, J.M.; Veličković, A.V.; Stamenković, O.S.; Rajković, K.M.; Milić, P.S.; Veljković, V.B. Optimization of sunflower oil ethanolysis catalyzed by calcium oxide: RSM versus ANN-GA. Energy Convers. Manag. 2015, 105, 1149-1156. [CrossRef]

28. Dalena, F.; Senatore, A.; Marino, A.; Gordano, A.; Basile, M.; Basile, A. Methanol production and applications: An overview. In Methanol: Science and Engineering; Elsevier: Amsterdam, The Netherlands, 2017; pp. 3-28.

29. Sarkar, N.; Ghosh, S.K.; Bannerjee, S.; Aikat, K. Bioethanol production from agricultural wastes: An overview. Renew. Energy 2012, 37, 19-27. [CrossRef]

30. Watcharathamrongkul, K. Calcium oxide based catalysts for ethanolysis of soybean oil. Songklanakarin J. Sci. Technol. 2010, 32, 627-634.

31. Velickovic, A.; Avramovic, J.; Stamenkovic, O.; Veljkovic, V. Kinetics of the sunflower oil ethanolysis using $\mathrm{CaO}$ as catalyst. Chem. Ind. Chem. Eng. Q. 2016, 22, 409-418. [CrossRef]

32. Rashid, U.; Ibrahim, M.; Ali, S.; Adil, M.; Hina, S.; Bukhari, I.H.; Yunus, R. Comparative study of the methanolysis and ethanolysis of Maize oil using alkaline catalysts. Grasas Aceites 2012, 63, 35-43. [CrossRef]

33. Verma, P.; Sharma, M.P. Comparative analysis of effect of methanol and ethanol on Karanja biodiesel production and its optimisation. Fuel 2016, 180, 164-174. [CrossRef]

34. García, M.; Gonzalo, A.; Sánchez, J.L.; Arauzo, J.; Simoes, C. Metanolysis and ethanolysis of animal fats: A comparative study of the influence of alcohols. Chem. Ind. Chem. Eng. Q. 2011, 17, 91-97. [CrossRef]

35. Meneghetti, S.M.P.; Meneghetti, M.R.; Wolf, C.R.; Silva, E.C.; Lima, G.E.S.; de Lira Silva, L.; Serra, T.M.; Cauduro, F.; de Oliveira, L.G. Biodiesel from castor oil: A comparison of ethanolysis versus methanolysis. Energy Fuels 2006, 20, 2262-2265. [CrossRef]

36. Adewale, P.; Dumont, M.J.; Ngadi, M. Recent trends of biodiesel production from animal fat wastes and associated production techniques. Renew. Sustain. Energy Rev. 2015, 45, 574-588. [CrossRef]

37. Fat Minami-Nutrition. Available online: https://socratic.org/questions/how-do-lipids-affect-the-digestivesystemhttp://www.minami-nutrition.co.uk/website/absorption.php (accessed on August 2006).

38. Woodgate, S.L.; Van der Veen, J.T. Fats and Oils-Animal Based. In Food Processing: Principles and Applications, 2nd ed.; Clark, S., Jung, S., Lamsal, B., Eds.; John Wiley \& Sons.: Hoboken, NJ, USA, 2014; pp. 481-499.

39. Azócar, L.; Ciudad, G.; Heipieper, H.J.; Muñoz, R.; Navia, R. Improving fatty acid methyl ester production yield in a lipase-catalyzed process using waste frying oils as feedstock. J. Biosci. Bioeng. 2010, 109, 609-614. [CrossRef] [PubMed]

40. Wyatt, V.T.; Hess, M.A.; Dunn, R.O.; Foglia, T.A.; Haas, M.J.; Marmer, W.N. Fuel properties and nitrogen oxide emission levels of biodiesel produced from animal fats. J. Amer Oil Chem Soc. 2005, 82, 585-591. [CrossRef]

41. Dias, J.M.; Alvim-ferraz, M.C.M.; Almeida, M.F. Mixtures of vegetable oils and animal fat for biodiesel production: Influence on product composition and quality. Energy Fuels 2008, 20, 3889-3893. [CrossRef]

42. Leung, D.Y.C.; Guo, Y. Transesterification of neat and used frying oil: Optimization for biodiesel production. Fuel Process. Technol. 2006, 87, 883-890. [CrossRef]

43. Charoenchaitrakool, M.; Thienmethangkoon, J. Statistical optimization for biodiesel production from waste frying oil through two-step catalyzed process. Fuel Process. Technol. 2011, 92, 112-118. [CrossRef]

44. Chakraborty, R.; Gupta, A.K.; Chowdhury, R. Conversion of slaughterhouse and poultry farm animal fats and wastes to biodiesel: Parametric sensitivity and fuel quality assessment. Renew. Sustain. Energy Rev. 2014, 29, 120-134. [CrossRef]

45. Espinosa, M.; Canielas, L.; Silvana, M.; Moraes, A.; Schmitt, C.; Assis, R.; Rodrigues, S.; Regina, M.; Rodrigues, A.; Bastos, E. Beef tallow biodiesel produced in a pilot scale. Fuel Process. Technol. 2009, 90, 570-575.

46. Ito, T.; Sakurai, Y.; Kakuta, Y.; Sugano, M.; Hirano, K. Biodiesel production from waste animal fats using pyrolysis method. Fuel Process. Technol. 2012, 94, 47-52. [CrossRef]

47. Dias, J.M.; Ferraz, C.A.; Almeida, M.F. Using mixtures of waste frying oil and pork lard to produce biodiesel. Energy Fuels 2008, 22, 3889-3893.

48. Boey, P.L.; Maniam, G.P.; Hamid, S.A.; Ali, D.M.H. Crab and cockle shells as catalysts for the preparation of methyl esters from low free fatty acid chicken fat. J. Am. Oil Chem. Soc. 2011, 88, 283-288. [CrossRef] 
49. Maniam, G.P.; Hindryawati, N.; Nurfitri, I.; Manaf, I.S.A.; Ramachandran, N.; Rahim, M.H.A. Utilization of waste fat from catfish (Pangasius) in methyl esters preparation using $\mathrm{CaO}$ derived from waste marine barnacle and bivalve clam as solid catalysts. J. Taiwan Inst. Chem. Eng. 2015, 49, 58-66. [CrossRef]

50. Aryee, A.N.A.; Simpson, B.K.; Cue, R.I.; Phillip, L.E. Enzymatic transesterification of fats and oils from animal discards to fatty acid ethyl esters for potential fuel use. Biomass Bioenergy 2011, 35, 4149-4157. [CrossRef]

51. Behçet, R. Performance and emission study of waste anchovy fish biodiesel in a diesel engine. Fuel Process. Technol. 2011, 92, 1187-1194. [CrossRef]

52. Knothe, G.; Razon, L.F. Biodiesel fuels. Prog. Energy Combust. Sci. 2017, 58, 36-59. [CrossRef]

53. Živković, S.B.; Veljković, M.V.; Banković-Ilić, I.B.; Krstić, I.M.; Konstantinović, S.S.; Ilić, S.B.; Avramović, J.M.; Stamenković, O.S.; Veljković, V.B. Technological, technical, economic, environmental, social, human health risk, toxicological and policy considerations of biodiesel production and use. Renew. Sustain. Energy Rev. 2017, 79, 222-247. [CrossRef]

54. Canakci, M. The potential of restaurant waste lipids as biodiesel feedstocks. Bioresour. Technol. 2007, 98, 183-190. [CrossRef]

55. Index Mundi Commodity Prices. Available online: https://www.indexmundi.com/commodities/ (accessed on 5 February 2019).

56. Grenea WASTE-BASED MARKET PERFORMANCE. Available online: https://www.greenea.com/en/marketanalysis/ (accessed on 5 February 2019).

57. EFPRA. What are the Three Categories? Available online: http://efpra.eu/which-byproducts-rendered/ (accessed on 22 November 2018).

58. Meeker, D.L. Essential Rendering, All About The Animal By-Products Industry; The National Renderers Association: Alexandria, VA, USA, 2006; ISBN 0965466035.

59. Jayathilakan, K.; Sultana, K.; Radhakrishna, K.; Bawa, A.S. Utilization of byproducts and waste materials from meat, poultry and fish processing industries: A review. J. Food Sci. Technol. 2012, 49, 278-293. [CrossRef]

60. Woodgate, S.; van der Veen, J. The role of fat processing and rendering in the European Union animal production industry. Biotechnol. Agron. Soc. Environ. 2004, 8, 283-294.

61. Giriprasad, R.; Sharma, H.; Goswami, M. Animal fat-processing and its quality control. J. Food Process. Technol. 2013, 4, 252. [CrossRef]

62. Knothe, G.; Krahl, J.; Van Gerpen, J. The Biodiesel Handbook; AOCS Press: Urbana, IL, USA, 2005; Volume 1.

63. Encinar, J.M.; Sánchez, N.; Martínez, G.; García, L. Study of biodiesel production from animal fats with high free fatty acid content. Bioresour. Technol. 2011, 102, 10907-10914. [CrossRef] [PubMed]

64. Dias, J.M.; Alvim-Ferraz, M.C.M.; Almeida, M.F.; Méndez Díaz, J.D.; Polo, M.S.; Utrilla, J.R. Selection of heterogeneous catalysts for biodiesel production from animal fat. Fuel 2012, 94, 418-425. [CrossRef]

65. Avhad, M.R.; Marchetti, J.M. A review on recent advancement in catalytic materials for biodiesel production. Renew. Sustain. Energy Rev. 2015, 50, 696-718. [CrossRef]

66. Pinzi, S.; Leiva-Candia, D.; López-García, I.; Redel-Macías, M.; Dorado, M. Latest trends in feedstocks for bioidesel production. Biofuels Bioprod. Biorefin. 2014, 8, 126-143. [CrossRef]

67. Pereira, G.G.; Garcia, R.K.A.; Ferreira, L.L.; Barrera-Arellano, D. Soybean and soybean/beef-tallow biodiesel: A comparative study on oxidative degradation during long-term storage. J. Am. Oil Chem. Soc. 2017, 94, 587-593. [CrossRef]

68. Canakci, M.; Sanli, H. Biodiesel production from various feedstocks and their effects on the fuel properties. J. Ind. Microbiol. Biotechnol. 2008, 35, 431-441. [CrossRef]

69. Sendzikiene, E.; Makareviciene, V.; Janulis, P. Oxidation stability of biodiesel fuel produced from fatty wastes. Pol. J. Environ. Stud. 2005, 14, 335-339.

70. Kumar, M.; Sharma, M.P. Selection of potential oils for biodiesel production. Renew. Sustain. Energy Rev. 2016, 56, 1129-1138. [CrossRef]

71. Gorji, A. Animal renewable waste resource as catalyst in biodiesel production. J. Biodivers. Environ. Sci. 2015, 7, 36-49.

72. Sharma, Y.C.; Singh, B.; Korstad, J. Latest developments on application of heterogenous basic catalysts for an efficient and eco friendly synthesis of biodiesel: A review. Fuel 2011, 90, 1309-1324. [CrossRef]

73. Shan, R.; Zhao, C.; Lv, P.; Yuan, H.; Yao, J. Catalytic applications of calcium rich waste materials for biodiesel: Current state and perspectives. Energy Convers. Manag. 2016, 127, 273-283. [CrossRef] 
74. Nasreen, S.; Nafees, M.; Qureshi, L.A.; Asad, M.S.; Sadiq, A.; Ali, S.D. Review of catalytic transesterifcation methods for biodiesel production. Intechopen 2015, 2, 64.

75. Guldhe, A.; Singh, B.; Mutanda, T.; Permaul, K.; Bux, F. Advances in synthesis of biodiesel via enzyme catalysis: Novel and sustainable approaches. Renew. Sustain. Energy Rev. 2015, 41, 1447-1464. [CrossRef]

76. Kouzu, M.; Hidaka, J.S. Transesterification of vegetable oil into biodiesel catalyzed by CaO: A review. Fuel 2012, 93, 1-12. [CrossRef]

77. Fjerbaek, L.; Christensen, K.V.; Norddahl, B. A review of the current state of biodiesel production using enzymatic transesterification. Biotechnol. Bioeng. 2009, 102, 1298-1315. [CrossRef] [PubMed]

78. Mata, T.M.; Mendes, A.M.; Caetano, N.S.; Martins, A.A. Properties and sustainability of biodiesel from animal fats and fish oil. Chem. Eng. Trans. 2014, 38, 175-180.

79. Alptekin, E.; Canakci, M.; Sanli, H. Biodiesel production from vegetable oil and waste animal fats in a pilot plant. Waste Manag. 2014, 34, 2146-2154. [CrossRef]

80. Araújo, B.Q.; Nunes, R.C.D.R.; De Moura, C.V.R.; De Moura, E.M.; Citó, A.M.D.G.L.; Dos Santos Júnior, J.R. Synthesis and characterization of beef tallow biodiesel. Energy Fuels 2010, 24, 4476-4480. [CrossRef]

81. Mata, T.M.; Cardoso, N.; Ornelas, M.; Neves, S.; Caetano, N.S. Evaluation of two purification methods of biodiesel from pork lard, beef tallow, and chicken fat. Energy Fuels 2011, 25, 4756-4762. [CrossRef]

82. De Almeida, V.F.; García-Moreno, P.J.; Guadix, A.; Guadix, E.M. Biodiesel production from mixtures of waste fish oil, palm oil and waste frying oil: Optimization of fuel properties. Fuel Process. Technol. 2015, 133, 152-160. [CrossRef]

83. Janchiv, A.; Oh, Y.; Choi, S. High quality biodiesel production from pork lard by high solvent additive. ScienceAsia 2012, 38, 95-101. [CrossRef]

84. Fadhil, A.B.; Al-tikrity, E.T.B.; Albadree, M.A. Transesterification of a novel feedstock, Cyprinus carpio fish oil: Influence of co-solvent and characterization of biodiesel. Fuel 2015, 162, 215-223. [CrossRef]

85. Ejikeme, P.M.; Anyaogu, I.D.; Egbuonu, C.A.C.; Eze, V.C. Pig-fat (Lard) derivatives as alternative diesel fuel in compression ignition engines. J. Pet. Technol. Altern. Fuels 2013, 4, 7-11.

86. Jeong, G.T.; Yang, H.S.; Park, D.H. Optimization of transesterification of animal fat ester using response surface methodology. Bioresour. Technol. 2009, 100, 25-30. [CrossRef] [PubMed]

87. Fadhil, A.B.; Ali, L.H. Alkaline-catalyzed transesterification of Silurus triostegus Heckel fish oil: Optimization of transesterification parameters. Renew. Energy 2013, 60, 481-488. [CrossRef]

88. Alptekin, E.; Canakci, M.; Sanli, H. Methyl ester production from chicken fat with high FFA. World Renew. Energy Congr. 2011, 1, 319-326.

89. Fayyazi, E.; Ghobadian, B.; Najafi, G.; Hosseinzadeh, B.; Mamat, R.; Hosseinzadeh, J. An ultrasound-assisted system for the optimization of biodiesel production from chicken fat oil using a genetic algorithm and response surface methodology. Ultrason. Sonochem. 2015, 26, 312-320. [CrossRef]

90. Liu, S.; Wang, Y.; Oh, J.H.; Herring, J.L. Fast biodiesel production from beef tallow with radio frequency heating. Renew. Energy 2011, 36, 1003-1007. [CrossRef]

91. Mata, T.M.; Cardoso, N.; Ornelas, M.; Neves, S.; Caetano, N.S. Sustainable production of biodiesel from tallow, lard and poultry fat and its quality evaluation. Chem. Eng. Trans. 2010, 19, 13-18.

92. Panneerselvam, S.I.; Miranda, L.R. Biodiesel production from mutton. In Proceedings of the 2011 IEEE Conference on Clean Energy and Technology (CET), Kuala Lumpur, Malaysia, 27-29 June 2011; pp. 83-86.

93. Cunha, A.; Feddern, V.; De Prá, M.C.; Higarashi, M.M.; De Abreu, P.G.; Coldebella, A. Synthesis and characterization of ethylic biodiesel from animal fat wastes. Fuel 2013, 105, 228-234. [CrossRef]

94. Stojković, I.J.; Miladinović, M.R.; Stamenković, O.S.; Banković-Ilić, I.B.; Povrenović, D.S.; Veljković, V.B. Biodiesel production by methanolysis of waste lard from piglet roasting over quicklime. Fuel 2016, 182, 454-466. [CrossRef]

95. Vafakish, B.; Barari, M. Biodiesel production by transesterification of tallow fat using heterogeneous catalysis. Kem. Ind. 2017, 66, 47-52. [CrossRef]

96. Soldi, R.A.; Oliveira, A.R.S.; Ramos, L.P.; César-Oliveira, M.A.F. Soybean oil and beef tallow alcoholysis by acid heterogeneous catalysis. Appl. Catal. A Gen. 2009, 361, 42-48. [CrossRef]

97. Hu, S.; Guan, Y.; Wang, Y.; Han, H. Nano-magnetic catalyst KF/CaO-Fe3O4for biodiesel production. Appl. Energy 2011, 88, 2685-2690. [CrossRef] 
98. Xu, G.; Cui, X.; Fan, S.; Zhang, B.; Song, H.; Yan, X.; Ma, X.; Kong, D. Optimization of transesterification of beef tallow for biodiesel production. In Proceedings of the 2011 Asia-Pacific Power and Energy Engineering Conference, Wuhan, China, 25-28 March 2011.

99. Atadashi, I.M.; Aroua, M.K.; Aziz, A.A. Biodiesel separation and purification: A review. Renew. Energy 2011, 36, 437-443. [CrossRef]

100. Alves, M.J.; Nascimento, S.M.; Pereira, I.G.; Martins, M.I.; Cardoso, V.L.; Reis, M. Biodiesel purification using microand ultrafiltration membranes. Renew. Energy 2013, 58, 15-20. [CrossRef]

101. Berrios, M.; Skelton, R.L. Comparison of purification methods for biodiesel. Chem. Eng. J. 2008, 144, 459-465. [CrossRef]

102. Atadashi, I.M.; Aroua, M.K.; Aziz, A.R.A.; Sulaiman, N.M.N. Refining technologies for the purification of crude biodiesel. Appl. Energy 2011, 88, 4239-4251. [CrossRef]

103. Veljković, V.B.; Banković-Ilić, I.B.; Stamenković, O.S. Purification of crude biodiesel obtained by heterogeneously-catalyzed transesterification. Renew. Sustain. Energy Rev. 2015, 49, 500-516. [CrossRef]

104. Atadashi, I.M. Purification of crude biodiesel using dry washing and membrane technologies. Alex. Eng. J. 2015, 54, 1265-1272. [CrossRef]

105. Reis, M.H.M.; Cardoso, V.L. Biodiesel production and purification using membrane technology. In Membrane Technologies for Biorefining; Elsevier: Amsterdam, The Netherlands, 2016; pp. 289-307.

106. European Committee for Standardization. European Standard EN 14214: 2012+A1; European Committee for Standardization: Brussels, Belgium, 2014; pp. 1-21.

107. U.S. Department of Energy. ASTM Biodiesel Specifications. Available online: https://afdc.energy.gov/fuels/ biodiesel_specifications.html (accessed on 5 November 2018).

108. Sakthivel, R.; Ramesh, K.; Purnachandran, R.; Mohamed Shameer, P. A review on the properties, performance and emission aspects of the third generation biodiesels. Renew. Sustain. Energy Rev. 2018, 82, 2970-2992. [CrossRef]

(C) 2019 by the authors. Licensee MDPI, Basel, Switzerland. This article is an open access article distributed under the terms and conditions of the Creative Commons Attribution (CC BY) license (http://creativecommons.org/licenses/by/4.0/). 